Research article

urn:1sid:zoobank.org:pub:AB5C3414-92EC-4CE3-8963-880E07648D11

\title{
Batillipes (Tardigrada, Arthrotardigrada) from the Portuguese coast with the description of two new species and a new dichotomous key for all species
}

\author{
Erika SANTOS ${ }^{1, *}$, Marcos RUBAL ${ }^{2}$, Puri VEIGA ${ }^{3}$, \\ Clélia M. C. da ROCHA ${ }^{4} \&$ Paulo FONTOURA ${ }^{5}$ \\ 1,2,3,5 Department of Biology, Faculty of Sciences, University of Porto, \\ Rua Campo Alegre, 4169-007, Porto, Portugal. \\ ${ }^{1,5}$ MARE, Marine and Environmental Sciences Centre, ISPA - Instituto Universitário, \\ Rua Jardim do Tabaco 34, 1149-041 Lisboa, Portugal. \\ ${ }^{2,3}$ CIIMAR/CIMAR, Laboratory of Coastal Biodiversity, Centre of Marine and Environmental \\ Research, Terminal de cruzeiros do Porto de Leixões, \\ Avenida General Norton de Matos S/N, 4450-208 Matosinhos Portugal. \\ ${ }^{4}$ Departamento de Biologia, Universidade Federal Rural de Pernambuco, Av. Manoel de Medeiros, \\ S/N, Dois Irmãos, Recife, PE, Brasil. 52171-090. \\ ${ }^{1}$ urn:1sid:zoobank.org:author:DEA16767-8305-4DB9-9645-A25D78E4859E \\ ${ }^{2}$ urn:1sid:zoobank.org:author:6301300F-5291-466D-A55E-04F94DB1956A \\ ${ }^{3}$ urn:lsid:zoobank.org:author:9214916F-BCCB-41F1-9360-40FD67E43FE2 \\ ${ }^{4}$ urn:lsid:zoobank.org:author:5EEF4476-86BF-48AB-83AC-2C7077B2C273 \\ ${ }^{5}$ urn:lsid:zoobank.org:author:37CD66D6-4527-47C2-BB66-F1A6CF94C4EB \\ *Corresponding author: erika.bio@gmail.com \\ ${ }^{2}$ Email: mrubal@ciimar.up.pt \\ 32Email: puri.sanchez@fc.up.pt \\ ${ }^{4}$ Email: cavalcanticlelia@yahoo.com.br \\ ${ }^{5}$ Email: pfontoura@fc.up.pt
}

\begin{abstract}
Five species of Batillipes Richters, 1909 were collected from subtidal sediments of the Portuguese coast. Two of them, B. algharbensis sp. nov. and B. lusitanus sp. nov., are new to science. Batillipes algharbensis sp. nov. differs from all the other Batillipes species in having the middle toes 3 on the fourth feet longer than middle toes 4 and by the presence of rounded lateral body projections between legs III and IV. Batillipes lusitanus sp. nov. has the middle toes of the fourth feet equal in length, but it exhibits a dorsal cuticular ornamentation, constituted by large pillars, similar to the cuticle of B. adriaticus Grimaldi de Zio, Morone De Lucia, D’Addabbo Gallo \& Grimaldi, 1979 and B. roscoffensis Kristensen, 1978. However, contrary to B. adriaticus, the caudal apparatus of B. lusitanus sp. nov. is a roundish cuticular expansion and $B$. roscoffensis lacks caudal apparatus. Batillipes adriaticus and B. phreaticus Renaud-Debyser, 1959 are new records for Portugal. Based on the examination of specimens of $B$. phreaticus collected at the Portuguese coast and their comparison with type material of this species and also of $B$. littoralis Renaud-Debyser, 1959, the toe arrangement patterns in species of Batillipes are clarified and a new identification key to species of this genus is provided.
\end{abstract}


Keywords. Atlantic Ocean, Batillipes algharbensis sp. nov., Batillipes lusitanus sp. nov., meiofauna, toe pattern.

Santos E., Rubal M., Veiga P., da Rocha C.M.C. \& Fontoura P. 2018. Batillipes (Tardigrada, Arthrotardigrada) from the Portuguese coast with the description of two new species and a new dichotomous key for all species. European Journal of Taxonomy 425: 1-32. https://doi.org/10.5852/ejt.2018.425

\section{Introduction}

The interstitial genus Batillipes, from the monogeneric family Batillipedidae Ramazzotti, 1962, was erected by Richters (1909) with the description of B. mirus Richters, 1909. The low number of taxonomic characters, traditionally used to distinguish species, and the intraspecific variability exhibited by some of those characters makes the taxonomy of the genus very problematic (e.g., McKirdy 1975; Kristensen 1978; Morone De Lucia et al. 1988; Villora-Moreno \& de Zio Grimaldi 1993; Gallo D'Addabbo et al. 2000; Kristensen \& Mackness 2000). Despite these difficulties the diversity of Batillipes is considerably high with 35 described species and distributed worldwide (Guidetti \& Bertolani 2005; Degma \& Guidetti 2007; Degma et al. 2009-2017; Jørgensen et al. 2014; Kaczmarek et al. 2015).

Regarding marine tardigrade surveys, the Northeast Atlantic coast is considered one of the best-known regions of the world (Kaczmarek et al. 2015). Unfortunately, within this region, the Iberian Atlantic coast, mainly the Portuguese coast, has been barely explored. In Portugal, until the beginning of this century, excluding the Azorean Sea, only four species of marine tardigrades were recorded (Rubal et al. 2013b): Batillipes similis Schulz, 1955; Echiniscoides sigismundi sigismundi Schultze, 1865; Echiniscoides sigismundi hispaniensis Kristensen \& Hallas, 1980 and Prostygarctus aculeatus Rubal, Veiga, Fontoura \& Sousa-Pinto, 2013. Recently, Rubal et al. $(2016,2017)$ added seven new records to the marine Portuguese tardigrade fauna, three of which belong to the genus Batillipes (B. minius Rubal, Veiga, Fontoura \& Sousa-Pinto, 2017, B. pennaki Marcus, 1946 and B. tubernatis Pollock, 1971) although the only Portuguese record of $B$. similis was questioned. This scenario justifies the urgent need for species inventories on this previously neglected region, aiming at contributing to a deeper knowledge of the Portuguese marine fauna and at understanding the peculiarities of the tardigrade biogeography.

In this paper, five species of Batillipes are reported from shallow subtidal sediments of sandy beaches, two of which, B. algharbensis sp. nov. and B. lusitanus sp. nov., are new to science and another two constitute new records for the Iberian Peninsula, B. adriaticus Grimaldi de Zio, Morone De Lucia, D'Addabbo Gallo \& Grimaldi, 1979 and for Portugal B. phreaticus Renaud-Debyser, 1959. Moreover, the presence of $B$. adriaticus on the South Atlantic coast of the Iberian Peninsula is the first record of this species outside the Mediterranean Sea.

In Batillipes, one of the more reliable taxonomic characters is the toe arrangement pattern, especially on feet of legs IV. This indicator was introduced by Pollock (1970a) and modified by Kristensen \& Mackness (2000), who proposed four patterns of toe lengths on the fourth feet. Based on the examination of B. phreaticus specimens (collected on the Portuguese coast and their comparison with type material of this species) and B. littoralis Renaud-Debyser, 1959 (deposited in the "Muséum national d'Histoire naturelle de Paris"), the toe arrangement patterns on the fourth feet in Batillipes species have been clarified. Additionally, a new dichotomous key to the identification of all known species of this genus is also provided.

\section{Material and methods}

Tardigrades were collected from shallow subtidal sediment samples (1-2 $\mathrm{m}$ depth in low tide) by free diving at eight sites on sandy beaches (Fig. 1) of the Portuguese Atlantic coast. Six sites were located 
on the Western coast: Afife Beach, Viana do Castelo (41 ${ }^{\circ} 35^{\prime} 28^{\prime \prime}$ N, $8^{\circ} 48^{\prime} 18^{\prime \prime}$ W) in May, 2014; Torreira Beach, Murtosa ( $40^{\circ} 45^{\prime} 33^{\prime \prime}$ N, $8^{\circ} 42^{\prime} 56^{\prime \prime}$ W) in April, 2014; Vieira Beach, Marinha Grande (39 $52^{\prime} 38^{\prime \prime} \mathrm{N}$, $8^{\circ} 58^{\prime} 518^{\prime \prime}$ W) in May, 2014; Baleal Sul Beach, Peniche (39²1'56" N, 9'20'34" W) in August 2014; Portinho da Arrábida Beach, Setúbal (38 28 $40^{\prime \prime}$ N, $8^{\circ} 58^{\prime} 55^{\prime \prime}$ W) in September, 2014; Vasco da Gama Beach, Sines (37 $57^{\prime} 13^{\prime \prime}$ N, $8^{\circ} 52^{\prime} 02^{\prime \prime}$ W) in September, 2014. Two sites were located on the South Coast: Meia-Praia Beach, Lagos ( $\left.37^{\circ} 7^{\prime} 1^{\prime \prime} \mathrm{N}, 8^{\circ} 38^{\prime} 37^{\prime \prime} \mathrm{W}\right)$ and Ilha de Tavira Beach, Tavira $\left(37^{\circ} 6^{\prime} 35^{\prime \prime} \mathrm{N}\right.$, $7^{\circ} 37^{\prime} 9^{\prime \prime} \mathrm{W}$ ), both in August 2014. Contrary to the other sampling sites, Afife Beach has many rocky substrates and, during sampling, the sediment was abundantly covered by algae (e.g., Sargassum muticum (Yendo) Fensholt, Bifurcaria bifurcata R. Ross and Cystoseira tamariscifolia Hudson).

At each site, five sediment samples, each with $100 \mathrm{~cm}^{3}$, were collected separated from each other about $5 \mathrm{~m}$. Later they were pooled into a single sample of $500 \mathrm{~cm}^{3}$. Samples were fixed in $4 \%$ buffered formaldehyde for further study. At the laboratory, sediments were washed and sieved through a $40 \mu \mathrm{m}$ mesh. Then tardigrades were sorted under a dissecting microscope $(50 \times$ Wild M5A, Wild-Heerbrug) and transferred to microscope slides. Some specimens were permanently mounted in polyvinyl alcohol (PVA) and others in glycerol that, after allowing a period of several days to evaporate to glycerine, were sealed with nail varnish. Microscope slides are deposited in the collection of tardigrades in the Department of Biology, Faculty of Sciences, University of Porto, Portugal.

For identification, tardigrades were observed, measured (all measurements are given in micrometers $(\mu \mathrm{m})$ and photomicrographed under 100× oil immersion, using a Zeiss Axioscope 40 Phase Contrast Microscope (PCM) and a Zeiss Axioimager 2 Differential Interference Contrast Microscope (DIC),

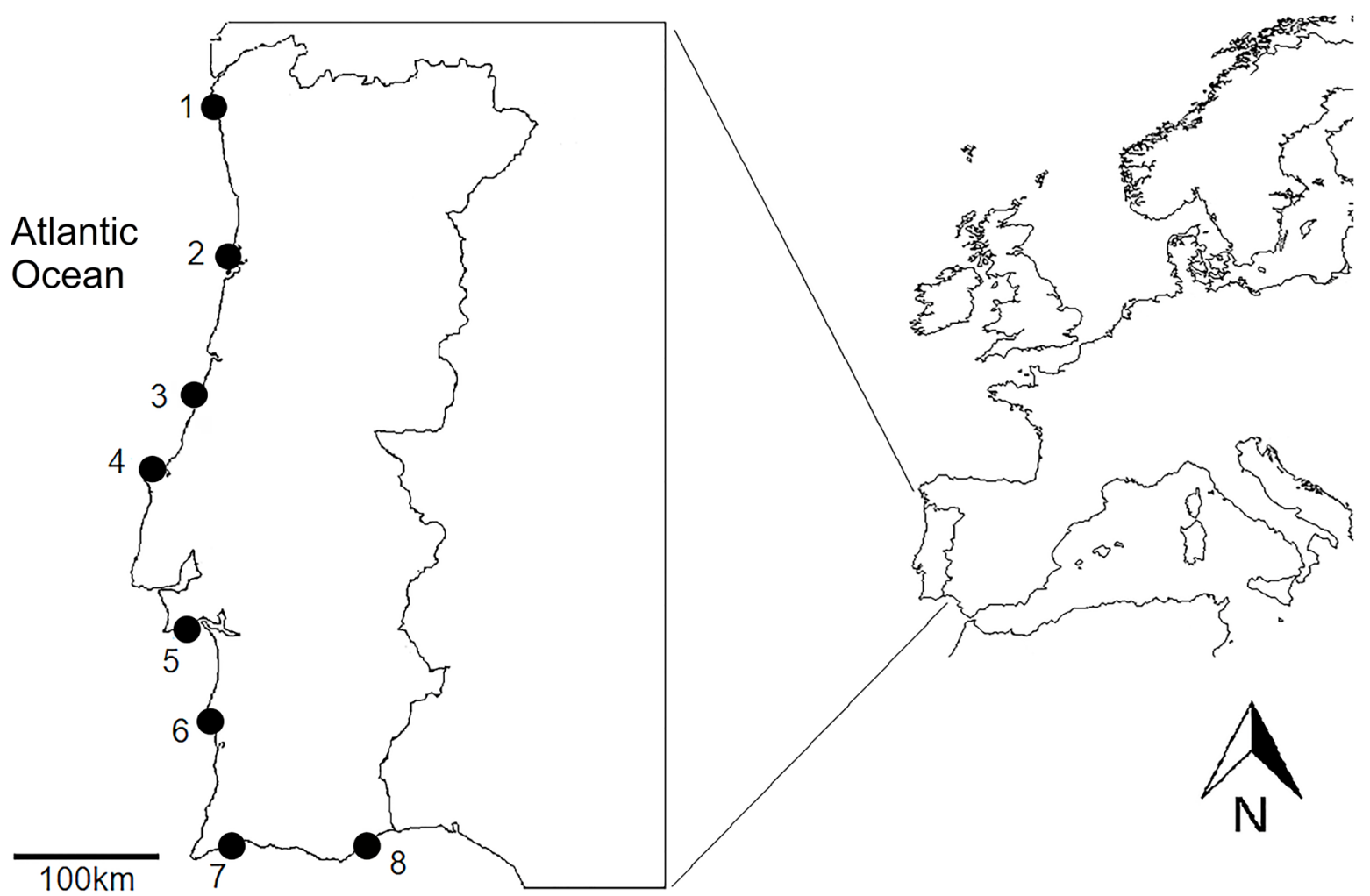

Fig. 1. Localities of the sampling sites along the Portuguese coast. 1. Afife Beach, 2. Torreira Beach. 3. Vieira Beach. 4. Baleal Sul Beach. 5. Portinho da Arrábida Beach. 6. Vasco da Gama Beach. 7. MeiaPraia Beach. 8. Ilha de Tavira Beach. 
both equipped with digital cameras and using Zen Imaging Software for light microscopy (from Zeiss). One specimen of $B$. lusitanus sp. nov. was prepared for scanning electron microscopy (SEM); this has been dehydrated through an ethanol/acetone series (50-100\%), freeze-dried, then sputter coated with a thin layer of gold and examined under high vacuum in a JEOL JSM 6301F/Oxford INCA Energy 350 microscope at the Materials Centre of the University of Porto (CEMUP).

For comparison, the holotype and a paratype (slides AA1287, AA1288) of B. littoralis, the holotype (slide AA1289) of B. phreaticus, all of them from Arcachon Bay (France), and a specimen of the latter species from Scotland (slide AR607), collected by Pollock in 1981, deposited in the collection "Méiofaune" at the Muséum national d'Histoire naturelle de Paris (MNHN), France, were examined. A specimen of B. phreaticus from Firemore Bay, Lock Ewe, Scotland from the Pollock's collection (kindly provided by Paul J. Bartels, Warren Wilson College, USA) was used for the same purpose. Finally, specimens of B. tubernatis, B. minius and misidentified B. similis (Rubal et al. 2016) from Portugal as well as Batillipes sp. 1 (Veiga et al. 2009) from Galicia (NW Spain) from the collection of the Department of Biology, Faculty of Sciences, University of Porto were also examined. Comparisons with other species were based on their descriptions in the literature (Marcus 1946; Schulz 1955; Renaud-Debyser 1959; de Zio 1962; Pollock 1970a, 1971; McKirdy 1975; Kristensen 1978; Grimaldi de Zio et al. 1979; VilloraMoreno \& de Zio Grimaldi 1993; Gallo D’Addabbo et al. 2005).

\section{Results}

A total of 440 specimens from five species of Batillipes were found in sediment samples at six of the surveyed sites. Fifty-five specimens of Halechiniscus greveni Renaud-Mornant \& Deroux, 1976 were also found. Tardigrades were not found in sediment samples from two of the surveyed sites: Torreira Beach and Vieira Beach.

\section{Taxonomic Accounts}

Phylum Tardigrada Doyère, 1840

Class Heterotardigrada Marcus, 1927

Order Arthrotardigrada Marcus, 1927

Family Batillipedidae Ramazzotti, 1962 (emended by Gallo D'Addabbo et al. 2005)

Genus Batillipes Richters, 1909

Batillipes adriaticus Grimaldi de Zio, Morone De Lucia, D’Addabbo Gallo \& Grimaldi, 1979

\section{Material examined}

PORTUGAL: 1 collected at Portinho da Arrábida Beach, mounted in PVA (slide C.IX-71), and 14 specimens $(9+q, 1$ $\uparrow, 3$ juveniles and 1 four-toed larva, all mounted in glycerol), collected at Vasco da Gama Beach (slides C.IX-75, C.IX-80-C.IX-91).

\section{Remarks}

The specimens clearly correspond to the original description of Grimaldi de Zio et al. (1979). The main characteristic of this species is its dorsal cuticle sculpture constituted by large pillars, appearing as large tubercles (diameter about 2-3 $\mu \mathrm{m}$ ); ventrally the cuticle exhibits the fine punctuation as do the majority of Batillipes species. Cephalic appendages have a lance-like tip and papillary secondary clavae are present. Between legs III and IV, an acute sculptured conical body projection is present. Lateral body projections between the first three pairs of legs are not referred to by Grimaldi de Zio et al. (1979). However, in some Portuguese specimens, small blunt ventro-lateral body projections are visible. The caudal appendage is a long spine inserted on a cylindrical base. Middle toes ( 3 and 4 ) on feet of legs IV are of similar length. Sensory organs are present on all legs, considerably long on legs IV. 
The specific characters of the species: dorsal sculpture, conical lateral body projection between legs III-IV and spine-like caudal appendage are already present in the four-toed larva.

\section{Distribution}

Up to now, this species had only been reported from the Mediterranean Basin (Adriatic Sea, Ionian Sea and Tyrrhenian Sea, see Kaczmarek et al. 2015). This is its first record for the Atlantic Ocean.

\section{Associated species \\ Batillipes phreaticus and $H$. greveni.}

Batillipes algharbensis sp. nov. urn:1sid:zoobank.org:act:005ABE3C-1A30-4E9C-8C29-2AD0F8AA3B3B

Figs 2-3, Table 1

\section{Diagnosis}

Batillipes with distinct head, separated from the body by a neck constriction followed by lateral processes. Primary clavae very thin and undivided. Strongly developed secondary clavae present. Cephalic cirri with spatula-like distal tips. Sensory spines on all legs. Sensory spine on leg I with spatula-like distal tip separated from basal portion by a van der Land's organ. On fourth feet, middle toes 3 and 4 of different lengths, with toe 3 longer than 4 . A dorsal papilla present at distal extreme of all legs. Blunt lateral body projections present between all leg pairs: faint between legs I-III and very well-developed between legs III-IV. The caudal apparatus consists of a sharp and long spine inserted in a slightly elongated swollen base. Dorsal cuticle coarsely punctated. Rosette-like female gonopore.

\section{Etymology}

The name refers to the region where the species was found, the Portuguese region of Algarve, from the Arabic 'Al Gharb' $(A l=$ the + Gharb $=$ West $)$; algharbensis $=$ inhabiting Algarve.

\section{Material examined}

\section{Holotype}

PORTUGAL: $q$ adult, collected at Meia-Praia Beach, Lagos, Algarve, $37^{\circ} 07^{\prime} 01^{\prime \prime} \mathrm{N}, 8^{\circ} 38^{\prime} 37^{\prime \prime} \mathrm{W}$, the only adult found, mounted in glycerol (slide C.VII-88).

\section{Paratype}

PORTUGAL: 1 four-toed larva, collected at Meia-Praia Beach, Lagos, Algarve, $37^{\circ} 07^{\prime} 01^{\prime \prime} \mathrm{N}, 8^{\circ} 38^{\prime} 37^{\prime \prime} \mathrm{W}$, mounted in glycerol (slide C.VII-89).

\section{Additional material}

SPAIN: 9 specimens ( 8 + 9 and 1 six-toed juvenile), collected in Galicia (NW Spain), at Rias of O Barqueiro ( $\left.43^{\circ} 44^{\prime} 37^{\prime \prime} \mathrm{N}, 7^{\circ} 39^{\prime} 06^{\prime \prime} \mathrm{W}-43^{\circ} 45^{\prime} 15^{\prime \prime} \mathrm{N}, 7^{\circ} 41^{\prime} 22^{\prime \prime} \mathrm{W}\right)$ and Foz $\left(43^{\circ} 33^{\prime} 47^{\prime \prime} \mathrm{N}, 7^{\circ} 15^{\prime} 19^{\prime \prime} \mathrm{W}-\right.$ $43^{\circ} 34^{\prime} 11^{\prime \prime} \mathrm{N}, 7^{\circ} 14^{\prime} 41^{\prime \prime} \mathrm{W}$ ) (slides GAL.I-9-GAL.I-17).

\section{Description}

Holotype, female with a body length $121.1 \mu \mathrm{m}$ (150.6 $\mu \mathrm{m}$ including the caudal apparatus) and $57.9 \mu \mathrm{m}$ wide between the third and fourth pair of legs (Fig. 2A-B; Table 1 for morphometrics). Eye spots not observed in mounted specimens. Trapezoid head (Fig. 3A-B) separated from the body by a neck constriction followed by lateral processes (body projection 1). Internal cephalic cirri inserted dorsally, bearing cirrophores (cirrophores ca $3.4 \mu \mathrm{m}$ long) (Fig. 3A). External cephalic cirri, with indistinct cirrophores, inserted more ventrally, near the common pedestal bearing lateral cirri $A$ and primary clavae 
Table 1. Measurements $(\mu \mathrm{m})$ of selected morphological structures from the holotype and paratype, a fourtoed larva, of Batillipes algharbensis sp. nov. from Portugal, and specimens from Galicia (NW Spain) (SD - Standard deviation; Range refers to the smallest and largest measured specimen/structure; $\mathrm{N}$ - number of specimens/structures measured).

\begin{tabular}{|c|c|c|c|}
\hline \multirow[b]{2}{*}{ Structures } & \multicolumn{2}{|c|}{ Specimens from Portugal } & \multirow{2}{*}{$\begin{array}{c}\text { Specimens from Galicia } \\
\text { Females and } \\
\text { six-toed juveniles } \\
\text { Mean } \pm \text { SD (Range); N }\end{array}$} \\
\hline & Holotype & Four-toed larva & \\
\hline Body length & 150.6 & 108 & $130.2 \pm 25.15(97.9-173.5) ; 9$ \\
\hline $\begin{array}{l}\text { Body length without caudal } \\
\text { apparatus }\end{array}$ & 121.1 & 87 & $104.1 \pm 18.95(80.5-134.5) ; 9$ \\
\hline Median cirrus & 16.1 & 14.9 & $14.7 \pm 1.87(12.1-17.5) ; 8$ \\
\hline Internal cirri & 17.6 & 16.3 & $19.2 \pm 3.50(14.9-24.3) ; 9$ \\
\hline External cirri & 14.3 & 13.5 & $14.6 \pm 3.51(9.5-20.7) ; 9$ \\
\hline Lateral cirri $A$ & 30.8 & 24.6 & $30.0 \pm 7.47(22.4-46.4) ; 9$ \\
\hline Primary clavae & 16.9 & 9.9 & $15.0 \pm 3.82(11.7-24.3) ; 9$ \\
\hline Cirri $E$ & 18.1 & 15.4 & $15.0 \pm 4.14(11.4-24.0) ; 8$ \\
\hline Leg I spine & 7.3 & 6.5 & $7.5 \pm 1.29(6.5-10.6) ; 9$ \\
\hline Leg II spine & 6.5 & 6.9 & $7.0 \pm 1.10(5.4-8.7) ; 7$ \\
\hline Leg III spine & 5.6 & 6.8 & $6.7 \pm 1.69(4.8-8.4) ; 5$ \\
\hline Leg IV sensory organ & 20.2 & 14.1 & $14.3 \pm 2.48(10.4-19.9) ; 9$ \\
\hline Body projection 1 & 3.9 & 2.2 & $2.5 \pm 0.49(1.9-3.1) ; 9$ \\
\hline Body projection 2 & 3.0 & 2.1 & $2.4 \pm 0.63(1.5-3.5) ; 9$ \\
\hline Body projection 3 & 4.7 & 2.3 & $3.3 \pm 1.21(1.9-5.0) ; 9$ \\
\hline Body projection 4 & 6.6 & 3.2 & $5.4 \pm 2.92(3.3-12.2) ; 9$ \\
\hline Caudal apparatus & 29.5 & 21 & $26.0 \pm 7.25(17.4-39.0) ; 9$ \\
\hline Leg I-III: Toe 1 & 7.3 & 3.2 & $7.7 \pm 2.10(5-10.8) ; 7$ \\
\hline Toe 2 & 3.9 & 7.9 & $4.2 \pm 1.02(3.3-6) ; 7$ \\
\hline Toe 3 & 10.7 & 4.4 & $11.2 \pm 2.80(7.9-15.4) ; 7$ \\
\hline Toe 4 & 7.2 & 8.6 & $7.7 \pm 1.52(5.7-10.0) ; 7$ \\
\hline Toe 5 & 12.1 & - & $12.7 \pm 3.03(8.2-16.7) ; 7$ \\
\hline Toe 6 & 8.0 & - & $8.6 \pm 1.91(5.7-10.8) ; 7$ \\
\hline Leg IV: Toe 1 & 11.0 & 6.8 & $10.5 \pm 2.61(7.3-15.2) ; 9$ \\
\hline Toe 2 & 13.6 & 10.7 & $13.7 \pm 4.29(9.1-22.8) ; 9$ \\
\hline Toe 3 & 8.6 & - & $8.6 \pm 2.00(6.8-12.5) ; 9$ \\
\hline Toe 4 & 6.5 & - & $6.2 \pm 1.77(4.3-8.9) ; 9$ \\
\hline Toe 5 & 14.1 & 7.9 & $14.3 \pm 2.79(10.7-20.3) ; 9$ \\
\hline Toe 6 & 8.7 & 4.8 & $8.6 \pm 1.94(5.8-11.8) ; 9$ \\
\hline Gonopore-Anus distance & 7.1 & - & $10.2 \pm 2.16(7.7-13.4) ; 7$ \\
\hline
\end{tabular}


(Fig. 3B). The median cirrus with a cirrophore (ca $3.5 \mu \mathrm{m}$ long). Lateral cirri $A$ located dorsally in relation to the unconstricted primary clavae (Fig. 3A). The primary clavae, with a van der Land's organ at the base, particularly thin (thinner than lateral cirri) and sharpened at the tip (Fig. 3B). In the frontal edge of the head, conspicuous and strongly developed dome-shaped secondary clavae (Fig. 3B, D) also present (major diameter $3.8 \mu \mathrm{m}$ ). All cephalic cirri, have long spatula-like swollen tips (Fig. 3A-B). Ovoid pharyngeal bulb $14 \mu \mathrm{m}$ long and $16.6 \mu \mathrm{m}$ wide. Ventral mouth opening in a protruded circular cone. Stylets and placoids not visible after slide mounting.

Blunt ventro-lateral body projections (body projections 2 to 4 , respectively from legs I to IV) present between all leg pairs: very small and difficult to see between the first three pairs of legs and welldeveloped between legs III-IV (Fig. 3C). The caudal apparatus is constituted by a long and sharp spine inserted in a slightly elongated swollen base (Figs 2A-B, 3E).

Sensory spines present on all legs, decreasing in length from leg I to leg III. First (Fig. 3D) and fourth (Fig. 3E) leg sensory organs with spatula-like tips similar to the ones of cephalic appendages and both divided into two parts, separated by a van der Land's organ. Basal and distal parts are respectively $4.8 \mu \mathrm{m}$ and $2.5 \mu \mathrm{m}$ long for the sensory organ on legs I and 12.6 and $7.6 \mu \mathrm{m}$ long for the sensory organ

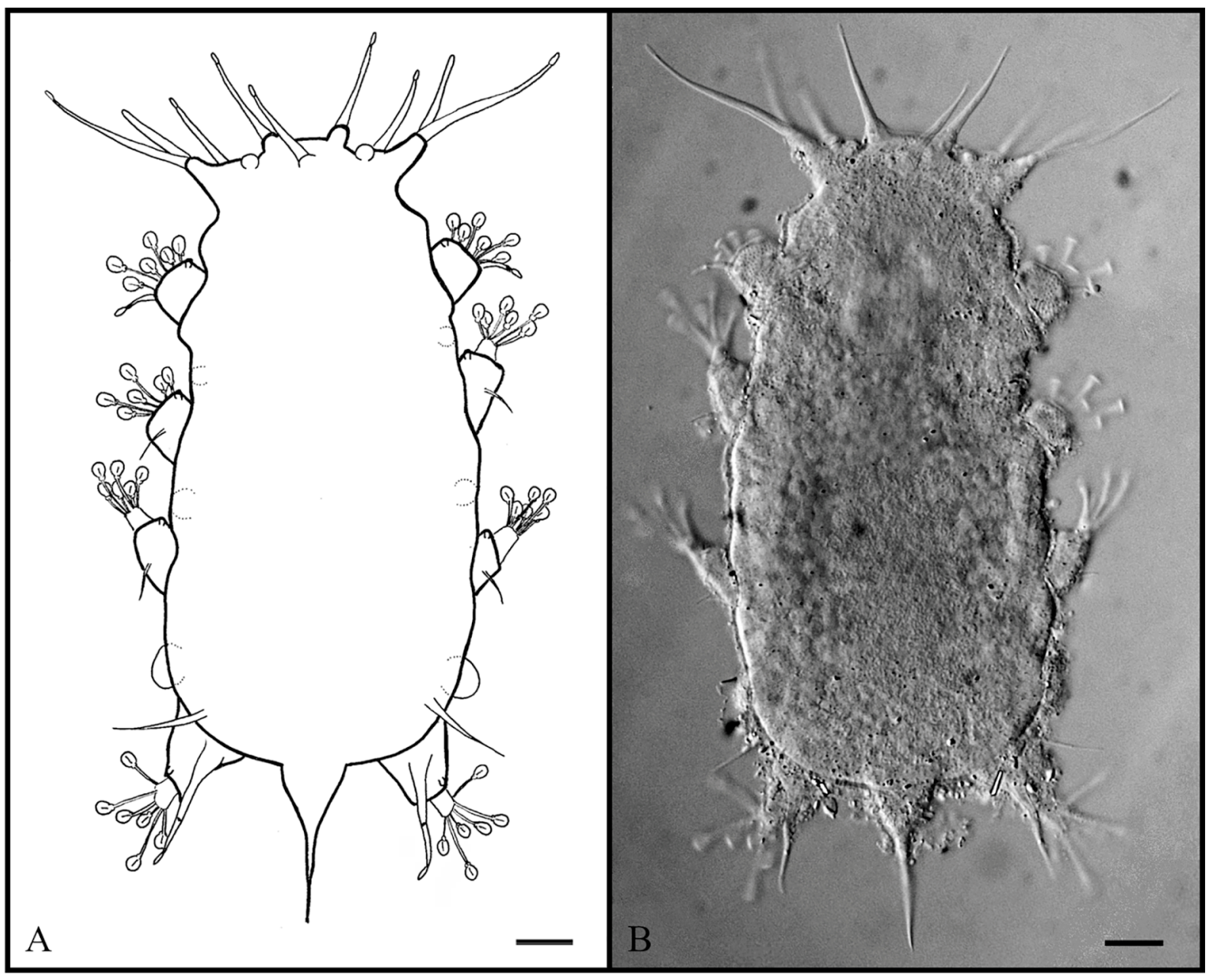

Fig. 2. Batillipes algharbensis sp. nov. A. Schematic drawing, dorsal view. B. Habitus of the holotype, o, dorsal view. Scale bars $=10 \mu \mathrm{m}$. 


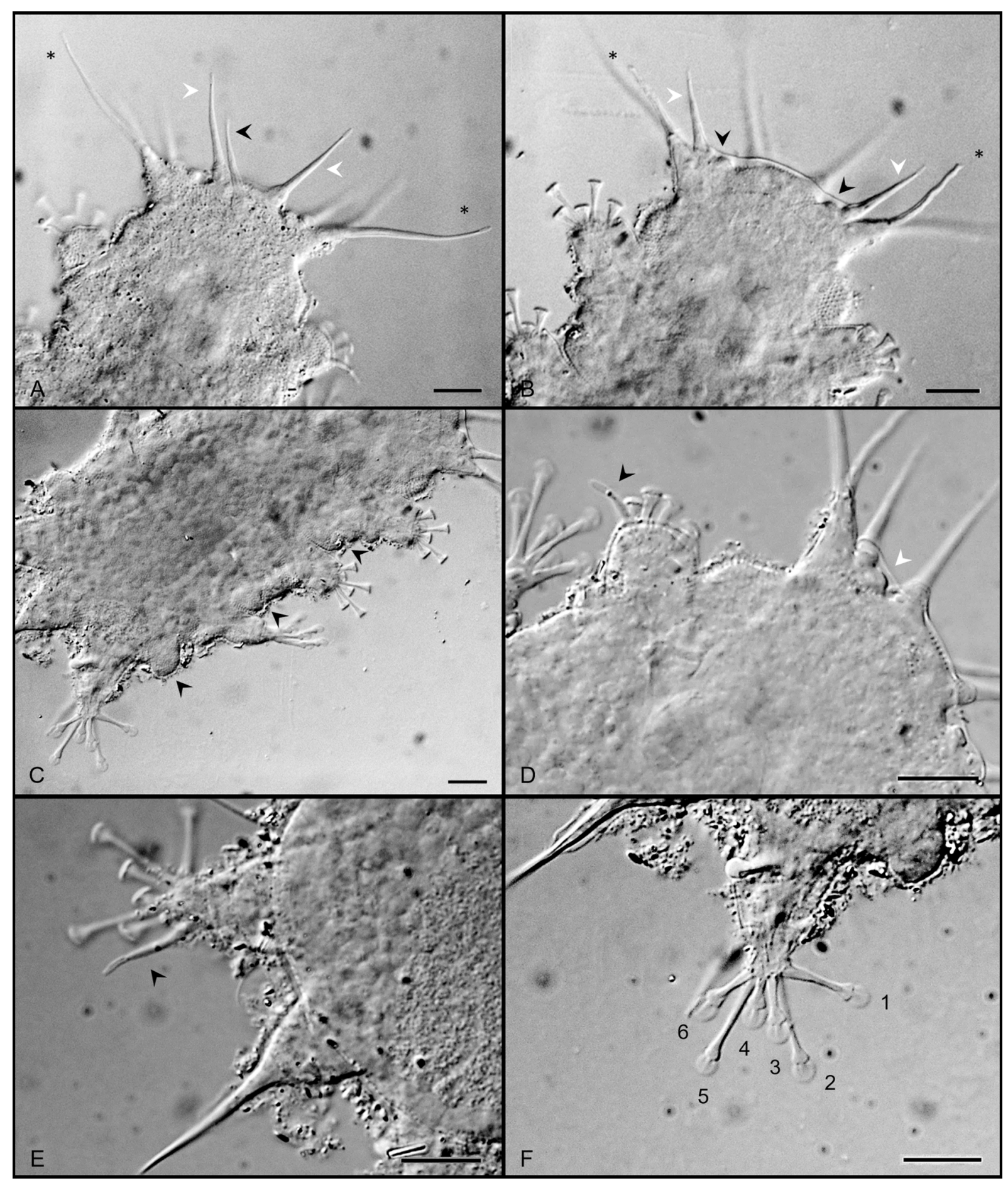

Fig. 3. Batillipes algharbensis sp. nov., holotype, ㅇ. A-B. Detail of the head. A. Dorsal view, showing median cirrus (black arrowhead), internal cirri (white arrowheads), lateral cirri (asterisks). B. Ventral view, showing primary clavae (asterisks), secondary clavae (black arrowheads), external cirri (white arrowheads). C-E. Body. C. Ventral view, showing ventro-lateral projections (black arrowheads). D. Anterior portion with details of leg spine I (black arrowhead), note the secondary clavae (white arrowhead). E. Posterior portion with details of leg sensory organ on leg IV (black arrowhead). F. Fourth leg with details of toes (1-6). Scale bars $=10 \mu \mathrm{m}$. 
on legs IV. The large spatula-like tips of sensory organs on legs IV are $3.7 \mu \mathrm{m}$ long. The entire fourth leg sensory organ is $20.2 \mu \mathrm{m}$ long. Sharply pointed cirri $E$ with small cirrophores present.

Telescopic legs with toes having the distal stalk enlarged distally (about $2.1 \mu \mathrm{m}$ wide), ovoid suction discs (diameter $2.9 \mu \mathrm{m}$ measured on toes of leg IV) with conspicuous braces. On the first three pair of legs, toe 2 is the shortest (considering toe 1 the most cephalically), toes 3 and 5 are the longest and toes 1,4 and 6 are medium sized. On feet of the fourth pair of legs, the middle toes 3 and 4 are of different lengths with toe 3 longer than toe 4; toes 2 and 5 are the longest, and toes 1 and 6 of intermediate size (Fig. 3F). A dorsal papilla (dark when observed under PCM) is present at the distal extreme of each leg.

Dorsal cuticle uniformly and coarsely punctated, about 9-10 pillars/ $10 \mu \mathrm{m}$ (each pillar about $1.4 \mu \mathrm{m}$ high), with barely visible transversal folds. Ventrally the cuticle punctation is more delicate. Body with a considerable amount of adherent detritus, mainly near the lateral body projections.

Rosette-shaped gonopore separated from the anus by a weakly defined groove. Other details of the gonoporal apparatus are not visible.

\section{Differential diagnosis}

Only one known species of Batillipes, B. tubernatis, originally described from the Northeast Atlantic Ocean (Scotland, Germany and England), shares with the new species the same toe arrangement pattern in the fourth feet, characterized by having toes 3 and 4 of different lengths and toe 3 longer than 4 . In the original description, the caudal region of $B$. tubernatis is described as being round without appendages (Pollock 1971). However, this character can be very variable and should be used with caution in species comparisons (Gallo D'Addabbo et al. 2000). Actually, in the emended description of B. tubernatis by McKirdy (1975), based on specimens from Florida (Gulf of Mexico), USA, (hereby designated B. tubernatis sensu McKirdy 1975), a strong swollen-based caudal spike was present in about $80 \%$ of the examined specimens.

Batillipes algharbensis sp. nov. can be clearly distinguished from $B$. tubernatis by the presence of ventrolateral body projections that are very well-developed between legs III-IV (lacking in all morphotypes of $B$. tubernatis). Moreover, in the new species, the primary clava is very thin and sharp-tipped, while in $B$. tubernatis it is short, thicker and tube-shaped. The dorsal cuticle is coarsely uniformly punctated in the new species $(9-10$ pillars $/ 10 \mu \mathrm{m}$ ) and finely punctated (about 14 pillars $/ 10 \mu \mathrm{m}$ ) in B. tubernatis whereas exhibiting apunctate areas in specimens from Florida. In addition, secondary clavae are conspicuous dome-shaped in the new species and indistinct in B. tubernatis. Finally, in B. tubernatis sensu McKirdy toe discs are quadrate with a slightly indented distal edge while in B. algharbensis sp. nov. toe discs are ovoid.

Body shape and caudal apparatus of B. algharbensis sp. nov. are very similar to B. spinicauda Gallo D'Addabbo, Sandulli \& de Zio Grimaldi, 2005, justifying a comparison between the two species. In addition to a different toe arrangement pattern in the fourth feet (Toe $3=$ Toe $4 \leq$ Toe 1 , Toe 6 in $B$. spinicauda), the new species differs from $B$. spinicauda in having undivided primary clavae, blunt body projections between legs III and IV (conical in B. spinicauda), toes in feet of legs I-III inserted at the same level (tarsus are oblique in B. spinicauda), and by lacking lateral papilla (malleolus) on leg IV.

\section{Associated species}

Batillipes lusitanus sp. nov., B. pennaki, B. phreaticus and H. greveni.

\section{Remarks}

The four-toed larva (morphometry in Table 1) is similar to the adult. 
Specimens collected in Galicia (NW Spain) and previously identified by Veiga et al. (2009) as Batillipes sp. 1 with similarities with $B$. spinicauda also exhibit the unique characters of $B$. algharbensis sp. nov. (Table 1). Therefore, they are assigned to B. algharbensis sp. nov.

Batillipes lusitanus sp. nov.

urn:1sid:zoobank.org:act:EA994F4C-C1D9-4B43-871C-327A3CB644C4

Figs 4-7; Table 2

\section{Diagnosis}

Batillipes with tubular undivided primary clavae with a wrinkled surface. Conspicuous papillar secondary clavae. Cephalic cirri with lance-like distal tips. Sensory spines on all legs. A small rigid process is present in the distal extreme of legs IV. Toes 3 and 4 on feet of legs IV equal in length. A distinct head separated from the body by a neck constriction followed by well-developed lateral processes. Ventro-lateral body projections between all leg pairs present: small, often indistinct, between legs IIII and well developed, semicircular or slightly pointed, between legs III-IV. The caudal apparatus consists of a semicircular cuticular expansion. Dorsal cuticle constituted by large pillars (ca $3.2 \mu \mathrm{m}$ high), appearing as large tubercles (diameter about 2-3 $\mu \mathrm{m}$ ). Ventral cuticle finely punctated. Rosettelike female gonopore separated from the trilobed anus by a groove.

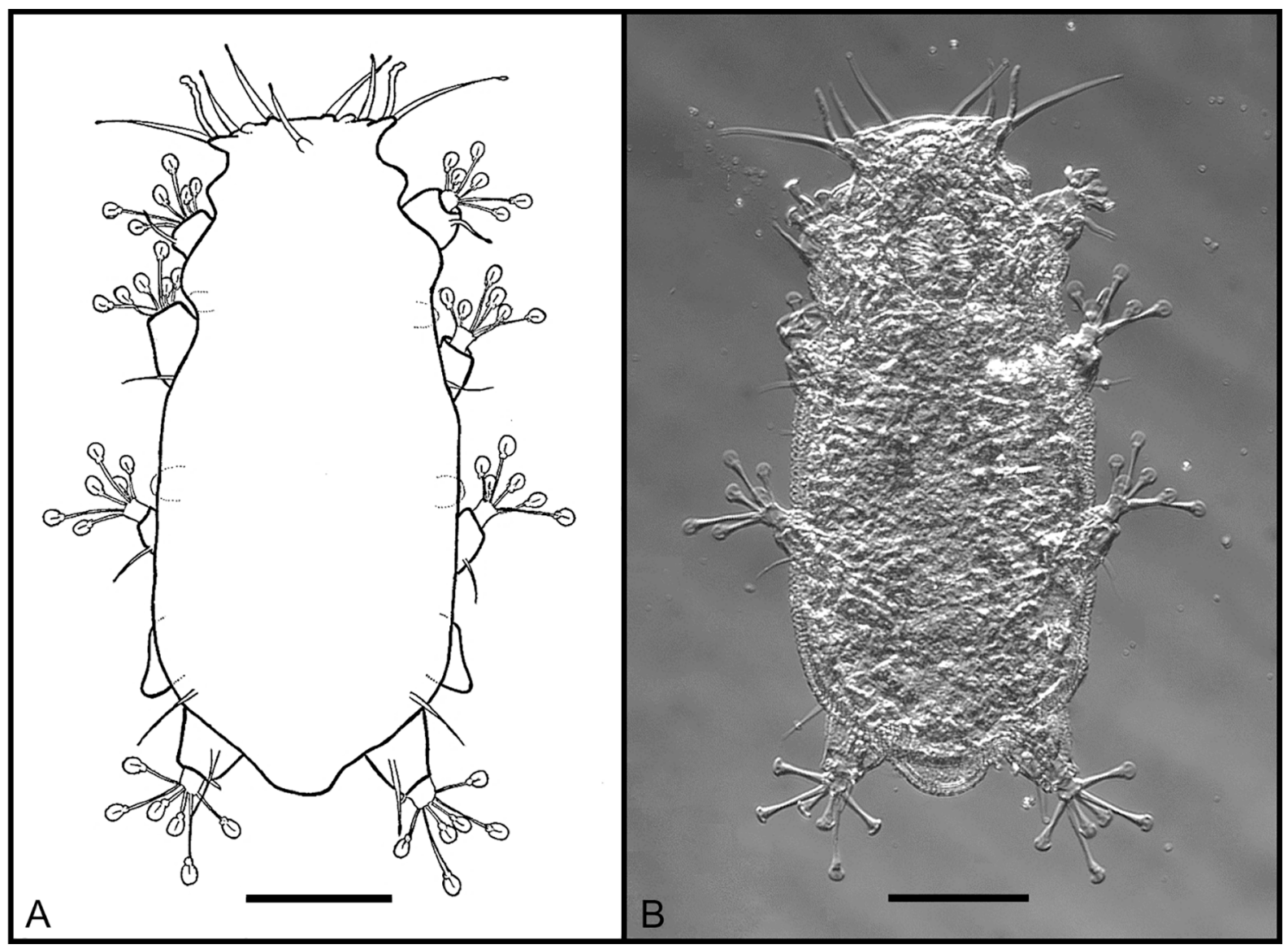

Fig. 4. Batillipes lusitanus sp. nov. A. Schematic drawing, dorsal view. B. Habitus of the holotype,, , ventral view. Scale bars $=50 \mu \mathrm{m}$. 


\section{Etymology}

The specific name 'lusitanus' refers to the locus typicus, Portugal, primitively known as Lusitânia, lusitanus = inhabiting Lusitânia.

\section{Material examined}

\section{Holotype}

PORTUGAL: $q$ adult, collected at Meia-Praia Beach, Lagos, Algarve, $37^{\circ} 7^{\prime} 1^{\prime \prime} \mathrm{N}, 8^{\circ} 38^{\prime} 37^{\prime \prime} \mathrm{W}$, mounted in glycerol (slide C.IX-1).

\section{Allotype}

PORTUGAL: $\widehat{O}^{\uparrow}$ adult, collected at Meia-Praia Beach, Lagos, Algarve, $37^{\circ} 7^{\prime} 1^{\prime \prime} \mathrm{N}, 8^{\circ} 38^{\prime} 37^{\prime \prime} \mathrm{W}$, mounted in glycerol (slide C.IX-2).

\section{Paratypes}

PORTUGAL: 78 specimens ( $19 q \propto,, 21 \hat{\jmath}, 37$ juveniles and 1 four-toed larva), collected at Meia-Praia Beach, $37^{\circ} 7^{\prime} 1^{\prime \prime} \mathrm{N}, 8^{\circ} 38^{\prime} 37^{\prime \prime} \mathrm{W}$, mounted in glycerol (slides C.IX-35-C.IX-66); 89 specimens (35 우우,

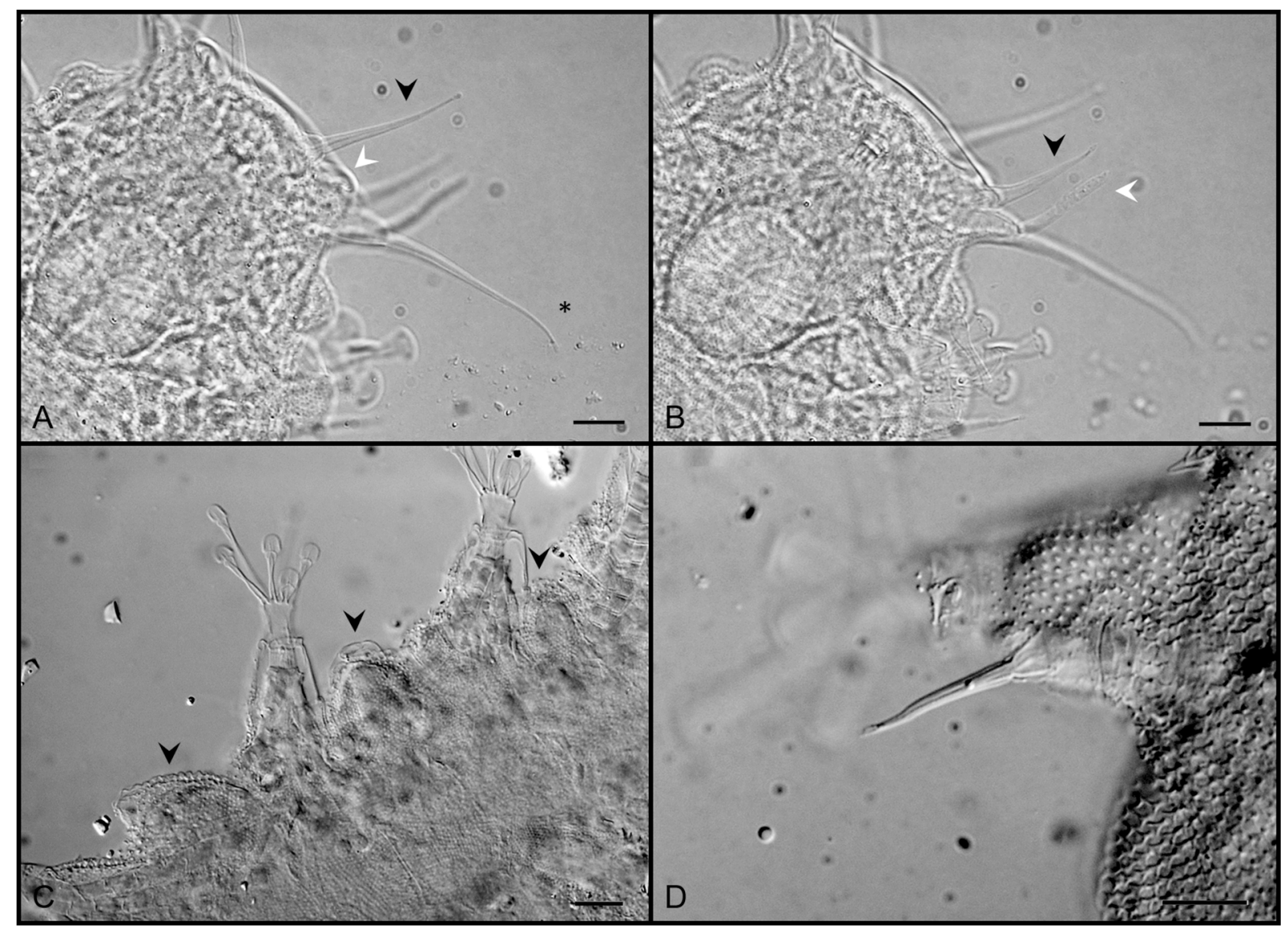

Fig. 5. Batillipes lusitanus sp. nov. A-B, D. Holotype, ㅇ. A-B. Detail of the head. A. Dorsal view, showing internal cirrus (black arrowhead), lateral cirrus (asterisk), secondary clava (white arrowhead). B. Ventral view, showing primary clava (white arrowhead), external cirrus (black arrowhead). C. Detail of body lateral projections of a paratype (slide C.IX-46) (black arrowheads); D. Detail of leg sensory organ on leg IV. Scale bars $=10 \mu \mathrm{m}$. 


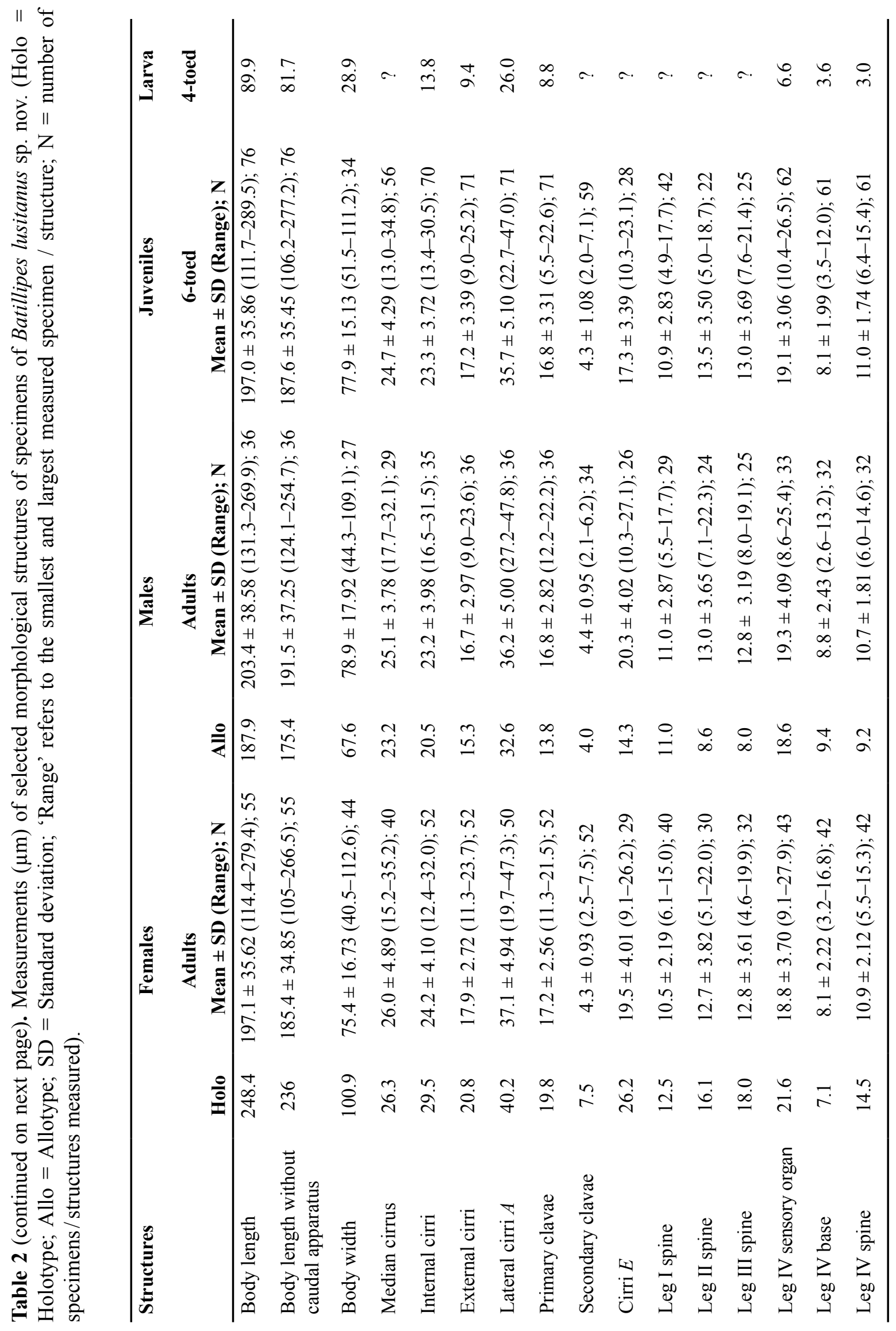




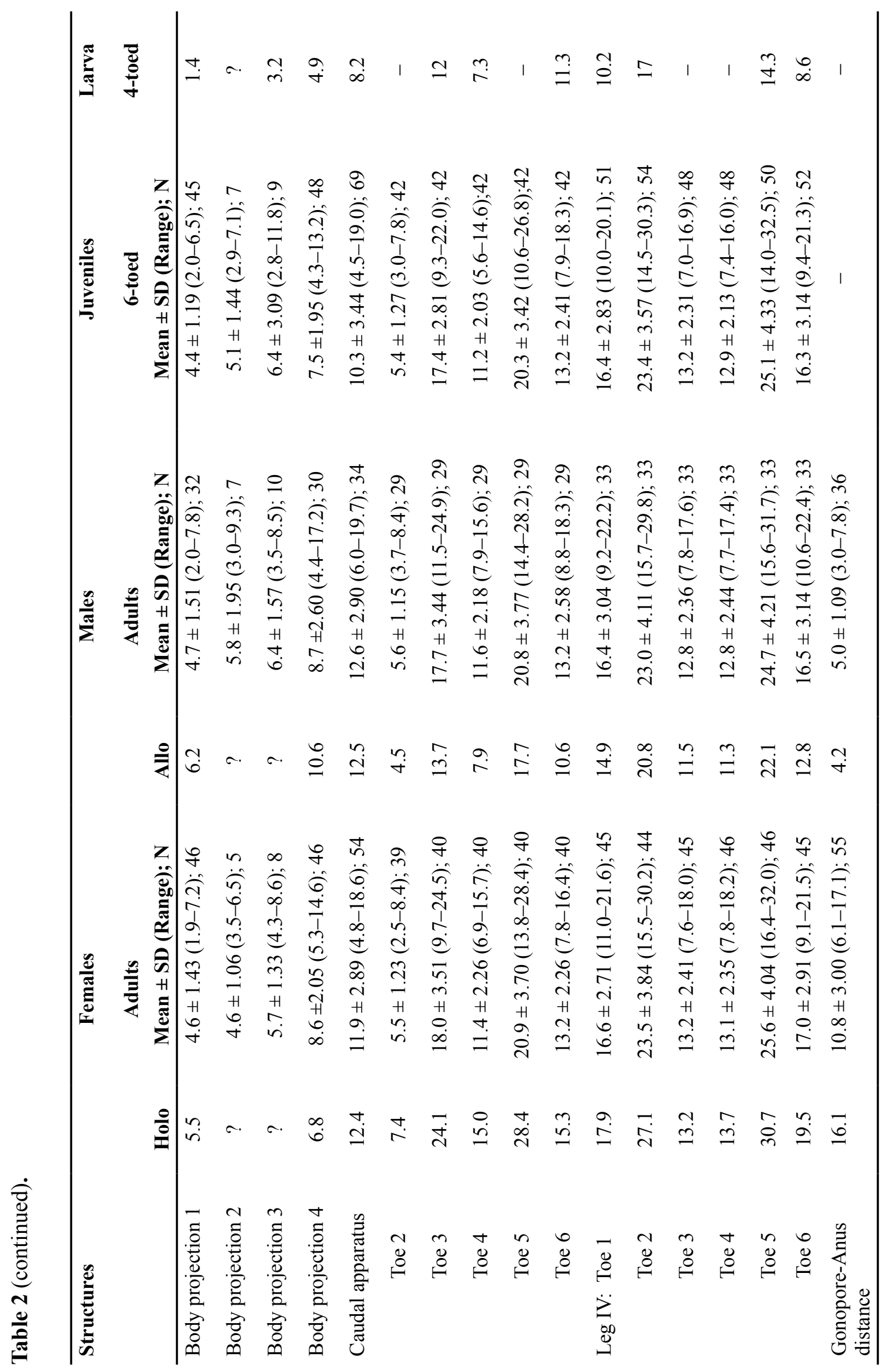




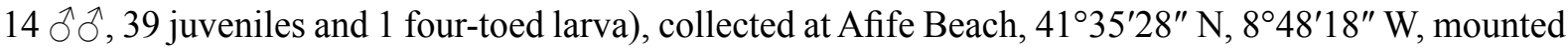
in PVA (slides C.IX-3-C.IX-34).

\section{Description}

Holotype, female of robust body $236 \mu \mathrm{m}$ long ( $248.4 \mu \mathrm{m}$ including the caudal apparatus) and $100.9 \mu \mathrm{m}$ wide between the third and fourth pair of legs (Figs 4A-B, Table 2 for morphometrics). Eyes not observed in mounted specimens. Trapezoid head (Figs 5A-B) separated from the body by a neck constriction followed by well-developed lateral processes (body projection 1). Head with eleven cephalic appendages: Internal cephalic cirri with cirrophores (ca $3.4 \mu \mathrm{m}$ long), are inserted dorsally on the frontal edge of the head (Fig. 5A). External cephalic cirri, with indistinct cirrophores, inserted more ventrally, near the lateral cirri $A$ and primary clavae (Fig. 5B). The median cirrus with cirrophore. The lateral cirrus $A$ located dorsally in relation to the unconstricted tubular primary clava. These two appendages share a common pedestal. A van der Land's organ present at the base of primary clavae, which have a wrinkled surface and exhibit a terminal hole (Figs 5A-B). An indentation present in the frontal edge of the head between the external cephalic cirrus and the pedestal with the primary clava and lateral cirrus. Papillar secondary clavae (Fig. 5A) well visible (major diameter ca $7.5 \mu \mathrm{m}$ long). Cephalic cirri, including

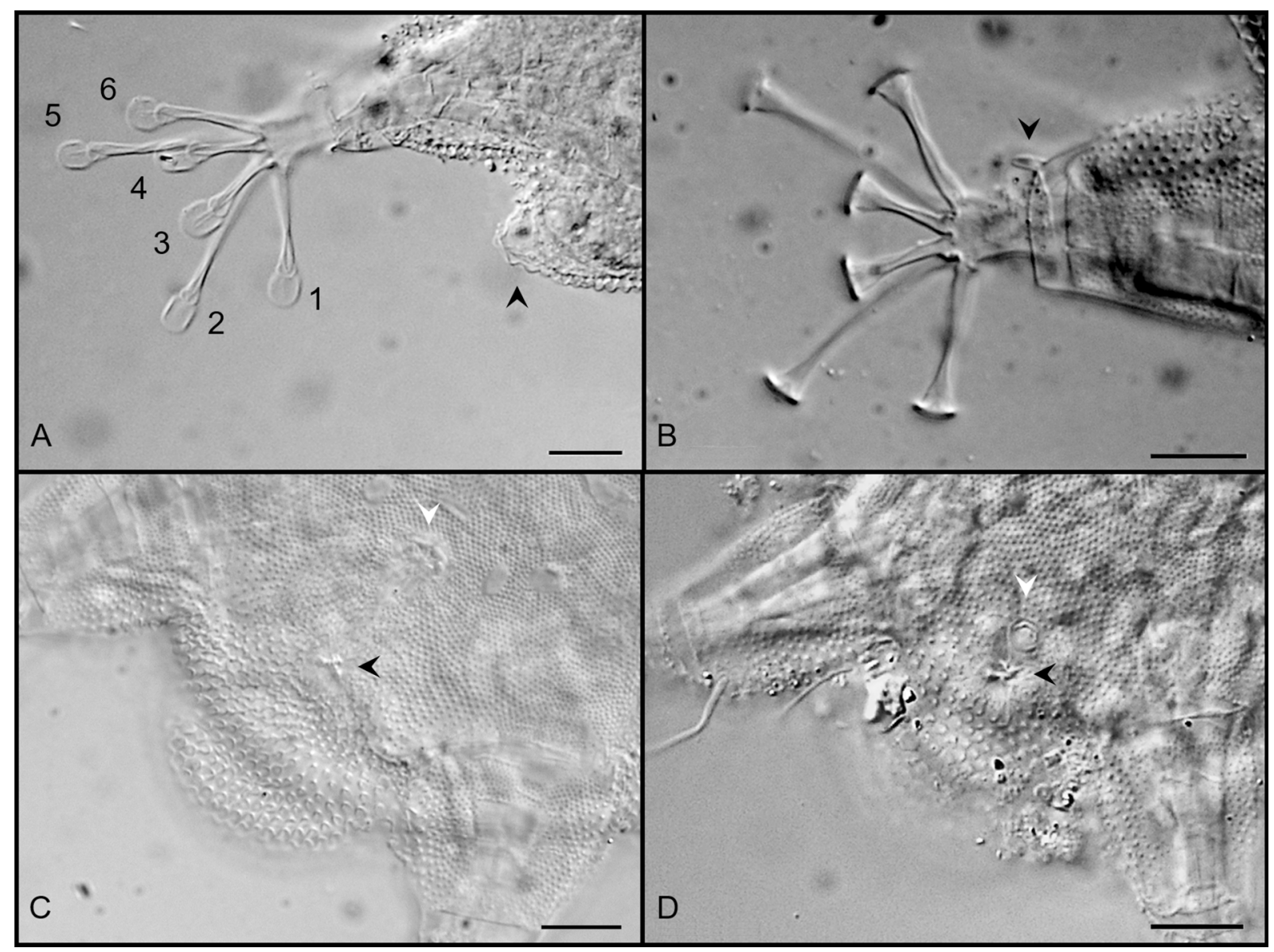

Fig. 6. Batillipes lusitanus sp. nov. A. Fourth leg of a paratype (slide C.IX-46) with details of toes (1-6), note the shape of the ventro-lateral projection between legs III-IV (black arrowhead). B. Fourth leg of a paratype (slide C.IX-1), showing the rigid process on the distal extreme (black arrowhead). C. Female gonopore (white arrowhead) and anus (black arrowhead). D. Male gonopore (white arrowhead) and anus (black arrowhead). Scale bars $=10 \mu \mathrm{m}$. 
the external cirri and the lateral cirri with swollen tips. Ventral mouth opening in a protruded circular structure. Ovoid pharyngeal bulb, $28.1 \mu \mathrm{m}$ long and $25.5 \mu \mathrm{m}$ wide, with placoids (ca $17.2 \mu \mathrm{m}$ long).

Well-developed blunt ventro-lateral processes between legs III and IV (body projection 4) (Figs 5C, 6A). The caudal apparatus consists of a prominent semicircular projection (Figs 4A-B, 6C, 7A-B).

Sensory spines present on all legs, increasing in length from leg I to IV. First and fourth leg sensory organs with swollen tips. The sensory organ on leg IV divided into a cirrophore (not measurable in the holotype but observed in paratypes) and a basal portion ( $7.1 \mu \mathrm{m}$ long) separated from a distal portion (14.5 $\mu \mathrm{m}$ long) by a van der Land's organ (Fig. 5D). Sharply pointed cirri $E$ with small cirrophores present.

Telescopic legs with toes with the distal stalk enlarged distally (ca $3.5 \mu \mathrm{m}$ wide), ovoid suction discs $(5.2 \times 5.1 \mu \mathrm{m})$ and conspicuous braces (Fig. 6A). On feet of the first three pairs of legs, toe 2 is the shortest, toes 3 and 5 are the longest and toes 1,4 and 6 are medium sized. On feet of the fourth pair of legs, (Fig. 6A-B) the medial toes 3 and 4 are equal in length. Toes 1 and 6 are medium sized; toe 2 and especially toe 5 are the longest. A small rigid process (ca $3 \mu \mathrm{m}$ long) is present in the distal extreme of legs IV (Fig. 6B).

The punctation of the dorsal cuticle is very peculiar. It is constituted by large pillars (about 5 pillars $/ 10 \mu \mathrm{m}$, each pillar with ca $3.6 \mu \mathrm{m}$ high) that, when observed under PCM and DIC, appear as large tubercles, especially if observed laterally (Fig. 7A-B). When observed under SEM, tubercles showed to be depressions that correspond to the wide top of pillars, surrounded by a epicuticular fold

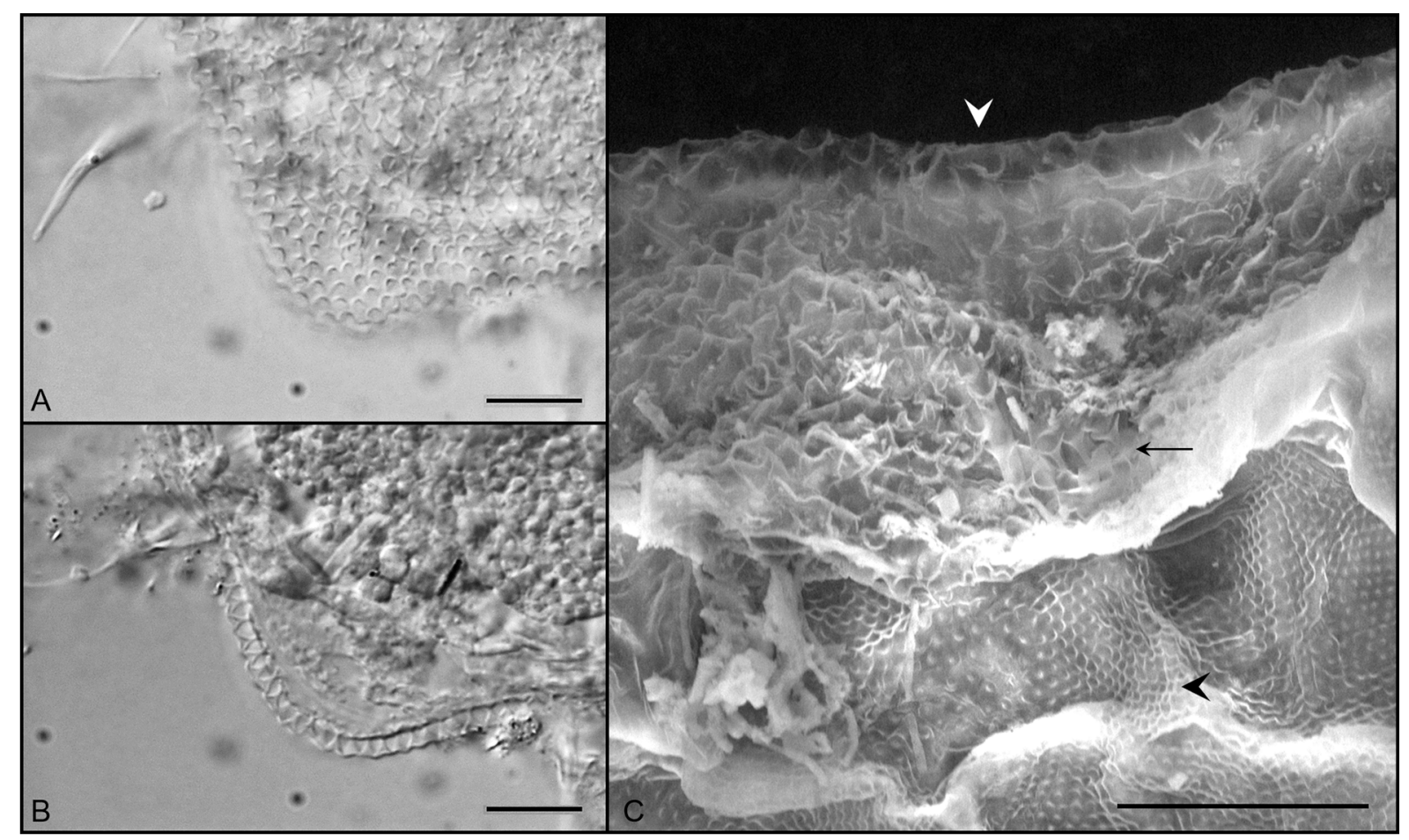

Fig. 7. Batillipes lusitanus sp. nov. A. Posterior portion of the body, showing the dorsal sculpture. B. Caudal apparatus, showing details of cuticular pillars. C. SEM photo showing the dorsal (white arrowhead) and ventral (black arrowhead) aspect of the cuticle. Pillars are also visible (black arrow). Scale bars $=10 \mu \mathrm{m}$. 
(Fig. 7C white arrowhead). Faint transverse cuticular folds are visible. Ventrally, the cuticle is finely punctuated (15-16 pillars/10 $\mu \mathrm{m})$ (Figs 6C-D, 7C black arrowhead).

Rosette-shaped gonopore separated from the anus by a well-defined groove (Fig. 6C).

\section{Differential diagnosis}

Excluding the new species, there are 26 species of Batillipes with the same toe arrangement pattern on feet of fourth legs as B. lusitanus sp. nov., which has the middle toes ( 3 and 4 ) on the fourth feet equal in length. However, only two of those species, B. roscoffensis Kristensen, 1978 and B. adriaticus, have the dorsal cuticular ornamentation, constituted by large pillars (ca $3.0 \mu \mathrm{m}$ high). Batillipes roscoffensis clearly differs from the new species in having scattered and randomly distributed dots ("small pox" according the terminology of Kristensen 1978). Those dots lack in all the other known Batillipes species and they were described by Kristensen (1978) under TEM (transmission electron microscopy), as elevations (of spongy electron dense mass, see Kristensen 1978: figs 13, 17). Moreover, in B. roscoffensis the caudal apparatus totally lacks and the lateral cirri $A$ is much longer than in $B$. lusitanus sp. nov. (cirrus $A$ ca $100 \mu \mathrm{m}$ long, corresponding to $40 \%$ of body length in $B$. roscoffensis, and less than $50 \mu \mathrm{m}$ long, corresponding to ca $20 \%$ of body length in the new species).

Batillipes lusitanus sp. nov. shares with $B$. adriaticus, the most similar species, the peculiar dorsal cuticle punctation constituted by large pillars, appearing as large tubercles. These two species can be clearly distinguished by the shape of the caudal apparatus that consists in a roundish cuticular expansion in $B$. lusitanus sp. nov. and in a sharp and long spine in B. adriaticus. The lateral body projection between legs III-IV is also blunt or slightly pointed in the new species while it is sharply pointed in $B$. adriaticus. Moreover, contrary to $B$. adriaticus, in the new species, a small rigid process is present in the distal extreme of legs IV and the surface of the primary clava is wrinkled. In addition, although with overlapping values, in adults of $B$. lusitanus sp. nov. the sensory organ on legs IV is slightly shorter than in B. adriaticus (range: 9-27 $\mu \mathrm{m}$ long in B. lusitanus sp. nov. and 20-40 $\mu \mathrm{m}$ long in B. adriaticus).

\section{Associated species}

Batillipes algharbensis sp. nov., B. pennaki, B. phreaticus and H. greveni.

\section{Remarks}

Measurements of structures obtained from specimens of the new species are provided in Table 2. Sexual dimorphism is not evident. Males are similar to females in both qualitative and quantitative characters, except for their circular gonopore with a cuticular crescent shaped fold and located nearer the anus (Fig. 6D). Juveniles, with six toes on each leg but without a visible gonopore, are also similar to adults (Table 2 for morphometrics). In the holotype, ventro-lateral body projections between legs I-III (body projections 2-3, respectively) are indistinct, but in some paratypes, although small, they are visible between all leg pairs (Fig. 5C). This variability could be attributed to the effect of microslide preparation highlighted by the ventral position of lateral projections. Among adults, the size and morphology of the caudal apparatus and lateral body projections, especially those between legs III and IV, show some variation, being perfectly semicircular, as in the holotype, or slightly pointed. In four-toed larvae, caudal apparatus and lateral projections are clearly conical.

The variability in shape of lateral projections and caudal apparatus was responsible for the misidentification of three specimens collected in 2011 in Portugal at Memória Beach, Matosinhos, $\left(41^{\circ} 13^{\prime} 49^{\prime \prime} \mathrm{N}, 8^{\circ} 43^{\prime} 21^{\prime \prime} \mathrm{W}\right.$ ) (Rubal et al. 2013b). These specimens were wrongly attributed to B. similis on account of the conical-shaped cuticular projections, evidenced by microslide preparation. A deeper examination showed that the middle toes on legs IV are equal in length and that the cuticle exhibits the 
same peculiar pattern of $B$. lusitanus sp. nov. Therefore, as suggested by Rubal et al. (2016, 2017), the presence of $B$. similis on the Portuguese coast cannot be assumed.

Batillipes pennaki Marcus 1946

\section{Material examined}

PORTUGAL: 19 , collected at Meia-Praia Beach, mounted in glycerol (slide C.IX-53) and 76 specimens (16 우 9,14 ㅎํ, 21 juveniles and 25 four-toed larvae) collected at Ilha de Tavira Beach, all mounted in glycerol (slides C.X-57-C.X-76).

\section{Remarks}

The specimens correspond well with the original description (Marcus 1946) and subsquent diagnosis (de Zio 1962; Pollock 1970a; McKirdy 1975; Ramazzotti \& Maucci 1983; Zawierucha et al. 2013).

\section{Distribution}

A common, worldwide distributed intertidal species that can occur in subtidal zones (for a more detailed geographic distribution see Kaczmarek et al. 2015). Batillipes pennaki was already known for Portugal, but up till now, only recorded in the northern region (Rubal et al. 2016) both on sandy beaches as well as on rocky shores.

\section{Associated species}

Batillipes algharbensis sp. nov., B. phreaticus, B. lusitanus sp. nov. and H. greveni.

Batillipes phreaticus Renaud-Debyser, 1959

Fig. 8

\section{Material examined}

PORTUGAL: $1 \hat{\partial}$, collected at Ilha de Tavira Beach, mounted in glycerol (slide C.10-79); 1 juvenil collected at Baleal Sul Beach, mounted in PVA (slide C.10-13); 34 specimens (22 9 ㅇ, 8 ô $\widehat{\partial}, 3$ juveniles and 1 four-toed larva), collected at Meia-Praia Beach, mounted in glycerol (slides C.VII.89, C.IX.1, C.IX-2; C.IX-37-C.IX-39, C.IX-41-C.IX-43, C.IX-47, C.IX-50-C.IX-52, C.IX-55-C.IX-58, C.IX60-C.IX-64, C.IX-66, C.IX-67); 116 specimens (42 우, 37 ô $\hat{\sigma}, 33$ juveniles and 4 four-toed larvae), collected at Vasco da Gama Beach, mounted in glycerol (slides C.IX-75-C.IX-86, C.IX-88-C.IX-98).

\section{Short description}

Distinct head separated from the body by a neck constriction followed by well-developed lateral processes (Fig. 8A). Eyes not observed in mounted specimens. Caudal apparatus constituted by one major pointed spine surrounded, at its base, by a crown of small accessory spines (2 to 6) (Fig. 8B). Paired internal and external cephalic cirri and median cirrus all with lance-like tips. Surface of primary clavae with black punctations, sharing the same pedestal with the lateral cirri $A$, that also have a lancelike tip. Papillar secondary clavae present. Dorsal cuticle shows fine punctuation, with pillars uniformly distributed. Single sharp conical body projections between legs III and IV (Fig. 8B). Lateral body projections between the first three pairs of legs often indistinct. When present, they are blunt between legs I-II and triangular between legs II-III. Dorsal cirri $E$ present. Sensory spines on all legs, longer on legs IV (Fig. 8B). Middle toes (3 and 4) on feet of legs IV (Fig. 8C) equal in length.

\section{Distribution}

Interstitial species recorded in the Eastern Atlantic region (Atlantic Ocean, North Sea, Irish Sea and Celtic Sea) and in the Mediterranean Basin (Balearic and Ionian Seas) where it has been recorded, 
mostly intertidally, but also subtidally (Kaczmarek et al. 2015). Batillipes phreaticus was recorded from the Galician coast, NW Spain (Veiga et al. 2009), but this is the first record from Portugal.

\section{Associated species}

Batillipes adriaticus, B. algharbensis sp. nov., B. lusitanus sp. nov., B. pennaki and H. greveni.

\section{Remarks}

In the original description of B. phreaticus from Arcachon Bay, France (Celtic Sea), the presence of lateral body projections between the first three pair of legs is not referred (Renaud-Debyser 1959).

Concerning toes, Renaud-Debyser (1959) states that they are similar to those of B. littoralis (also from Arcachon Bay), which are described in the same publication as having stalks of different lengths. However, the relative size of toes and details of the arrangement among feet were not referred by Renaud-Debyser (1959).

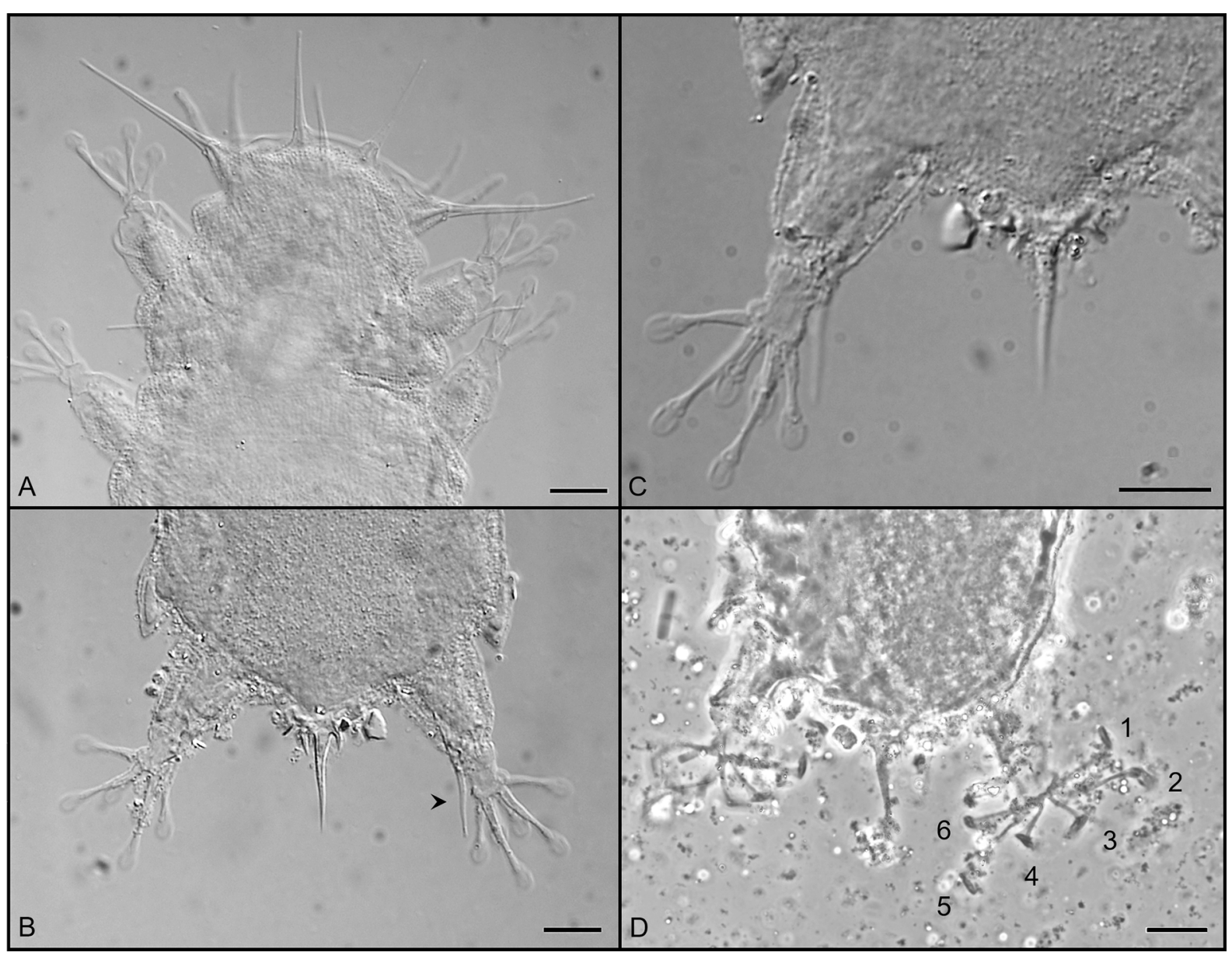

Fig. 8. Batillipes phreaticus Renaud-Debyser, 1959. A-C. Portuguese specimens. A. Anterior region of the body. B. Posterior region of the body, black arrow indicates fourth leg sensory organ. C. Detail of the fourth feet. D. Detail of the fourth feet showing the toe arrangement pattern of a specimen from Scotland in Pollock's collection. Scale bars $=10 \mu \mathrm{m}$. 
Specimens from England, Filey Beach and Stoup Beck Beach, Yorkshire, collected by Pollock (1971) and from Germany, Elbe Estuary (Riemann 1966) attributed to B. phreaticus, differed from the original description in some morphometric aspects and in having lateral body projections often present (Pollock 1971). Moreover, Pollock (1971) noticed that in English specimens, the middle toes (toes 3 and 4 ) on feet of legs IV were equal in length. Later, Villora-Moreno \& de Zio Grimaldi (1993), based on specimens collected on sandy beaches from the Mediterranean Sea (Balearic Sea), provided a redescription of the species, confirming the differences mentioned by Pollock (1971), regarding the original description: presence in adult specimens of a ventro-lateral body projection between legs II and III, and middle toes on feet of legs IV equal in length (toe pattern group A, Pollock 1970a). Despite his own observations, Pollock (1971) did not correct his proposal from 1970 of three different patterns of toe arrangement within Batillipes species, having included B. phreaticus in group $B$, which considers middle toes on feet of legs IV of different length and toe 1 equal to 3 , while $B$. littoralis have been included in group $C$ (middle toes on feet of legs IV of different length and toe 2 equal to 4 ).

The system of toe arrangement patterns on the fourth feet of species of Batillipes species was modified by Kristensen \& Mackness (2000), who proposed a fourth group (group $D$, constituted by species with middle toes of different length and also different from all the other toes). As previously proposed by Pollock (1970a), B. phreaticus and B. littoralis were kept in groups $B$ and $C$, respectively, by Kristensen \& Mackness (2000).

Taking into account the taxonomic importance of those characters (Gallo D'Addabbo et al. 2000), the examination of type material of those two species deposited in the collection of the MNHN was of primordial importance. This examination showed that the toe pattern of the fourth feet of $B$. littoralis perfectly matches the group $D$ proposed by Kristensen \& Mackness (2000). Concerning B. phreaticus, despite the poor condition of the specimen, the middle toes of the fourth feet seem to be equal in length and shorter than all the other, from which, toes 2 and 5 are the longest and about the same length, and toes 1 and 6, also similar in size and of intermediate length (toe pattern of group $A$ ). One of the examined specimens from Scotland collected by Pollock in 1981 also exhibits the middle toes of the fourth feet equal in length (Fig. 8D). Unfortunately, this character was not visible in the other Scottish specimen deposited in the MNHN (slide AR607).

Therefore, specimens from the Portuguese coast match with observations of Pollock (1971) and VilloraMoreno \& de Zio Grimaldi (1993). Ventro-lateral body projections between legs I-III were not observed in the type specimen, neither in the Scottish specimens. However, according to Pollock (1971) and as observed in Portuguese specimens, these lateral projections can be absent in some specimens or, as stated by Villora-Moreno \& de Zio Grimaldi (1993), are indistinct as a result of slide preparation. It is important to remark that in a few adult specimens from Portugal (three specimens from Vasco da Gama Beach and six from Portinho da Arrábida Beach) the main caudal spine was inserted on a wide conical base, lacking the basal crown of small accessory spines as it occurs in juveniles. This ontogenetic variability of the morphology of the caudal appendage was also referred by Villora-Moreno \& de Zio Grimaldi (1993).

\section{Discussion}

Fourteen marine tardigrade species are recorded from the Portuguese coast, of which 7 belong to the genus Batillipes: B. adriaticus, B. algharbensis sp. nov., B. lusitanus sp. nov., B. minius, B. pennaki, B. phreaticus and B. tubernatis (see also Rubal et al. 2016, 2017). Three of these species, the two newly described and B. minius, can be considered endemic to this region up to now. The distribution of $B$. adriaticus, up till now only known from the Mediterranean Sea, was considerably extended to the Atlantic Ocean. Batillipes phreaticus and B. tubernatis are typical of the NE Atlantic, while B. pennaki is considered cosmopolitan (Kaczmarek et al. 2015). 
Our study clearly shows that the diversity within the genus Batillipes is very high. Species of the genus (raised to 37 with this study) represent about $17 \%$ of all known marine heterotardigrade species (Guidetti \& Bertolani 2005; Degma \& Guidetti 2007; Degma et al. 2009-2017; Jørgensen et al. 2014) and 50\% of the diversity of Portuguese marine tardigrades. This number will probably increase in the near future (see Bartels et al. 2016). As shown in this research, many species are very similar to each other and this is problematic for the taxonomy of the genus. Difficulties are increased by the small number of taxonomic characters available and by the marked variability observed in some characters (e.g., McKirdy 1975; Gallo D'Addabbo et al. 2000). On the other hand, the use of morphometric data for taxonomic purposes must be carefully used because measurements can be biased by specimen orientation or by the physical slide mounting processes (see McGinty \& Higgins 1968; Pollock 1971; Kristensen 1978; Morone De Lucia et al. 1988; Villora-Moreno \& de Zio Grimaldi 1993; Gallo D'Addabbo et al. 2000; Kristensen \& Mackness 2000; Zawierucha et al. 2015; Fontoura et al. 2017; Santos et al. 2017). For these reasons, some of the old descriptions of species of Batillipes are incomplete and they may represent complexes of similar species, e.g., cosmopolitan B. mirus and B. pennaki as suggested by Zawierucha et al. (2013, 2015). In order to solve the problems that affect the taxonomy of the genus, research should focus on characters previously neglected for marine tardigrades (Gallo D'Addabbo et al. 2000). Toe arrangement patterns, especially on feet of fourth legs (Pollock 1970a; Kristensen \& Mackness 2000; Santos et al. 2017), toe disc shape (McKirdy 1975) and cuticle sculpture (Gallo D’Addabbo et al. 2000) are examples of such taxonomic characters, considered very reliable, especially if used in combination with other attributes.

As also shown in this study and confirmed with the examination of the type material of B. phreaticus and $B$. littoralis deposited in MNHN (Paris), inaccuracies on the definition of toe arrangement patterns on the fourth feet proposed by Pollock (1970a) and later modified by Kristensen \& Mackness (2000) were detected. Therefore, new modifications of this indicator are proposed. To apply this indicator, toes must be correctly numbered: Toe 1 being inserted on the tarsus most cephalically, then the other toes numbered sequentially in a clockwise direction, being toe 6 inserted on the tarsus most caudally (Fig. 9). This terminology avoids confusions introduced by using "external" and "internal" toes that is affected by the position of legs IV. Three major toe arrangement patterns can be recognized in Batillipes as follows (Table 3, Fig. 9):

- Group A: on the feet of legs IV, the middle toes 3 and 4 are similar in length; toes 2 and 5 are the longest ones and toes 1 and 6 of intermediate size. Toes 1 and 6 can be similar to middle toes 3 and 4, but not much shorter (Fig. 9A). This is the major group, constituted by 27 species. In three of these species, toes can be so short that suction discs resemble sessile (that is, the toe stalks are so short that they seem to be absent and, consequently, the discs seem to be directly inserted on the feet), especially in the middle toes (Fig. 9B).

- Group B: on the feet of legs IV, the middle toes 3 and 4 are clearly different in length; toes 2 and toes 5 are the longest and toes 1 and 6 of intermediate size (or similar but not shorter than middle toes 3 and 4). This group is subdivided into two subgroups: Subgroup B1: middle toe 3 shorter than middle toe 4 (Fig. 9C); Subgroup B2: middle toe 3 longer than middle toe 4 (Fig. 9D).

- Group C: on the feet of legs IV, the middle toes 3 and 4 are clearly different in length; toes 2 and toes 5 are the longest and toes 1 and 6 are the shortest (much shorter than middle toes 3 and 4) (Fig. 9E).

This clarification on toe arrangement patterns on feet of legs IV justifies the proposal of a new identification key to the species of the genus Batillipes (see below).

In addition, this study confirms the particular biogeographical position of the Portuguese coast which is supported by the first record outside the Mediterranean Sea of B. adriaticus. Similarly, Rubal et al. (2016) reported the first occurrence out of the Mediterranean Sea of Styraconyx sardiniae 


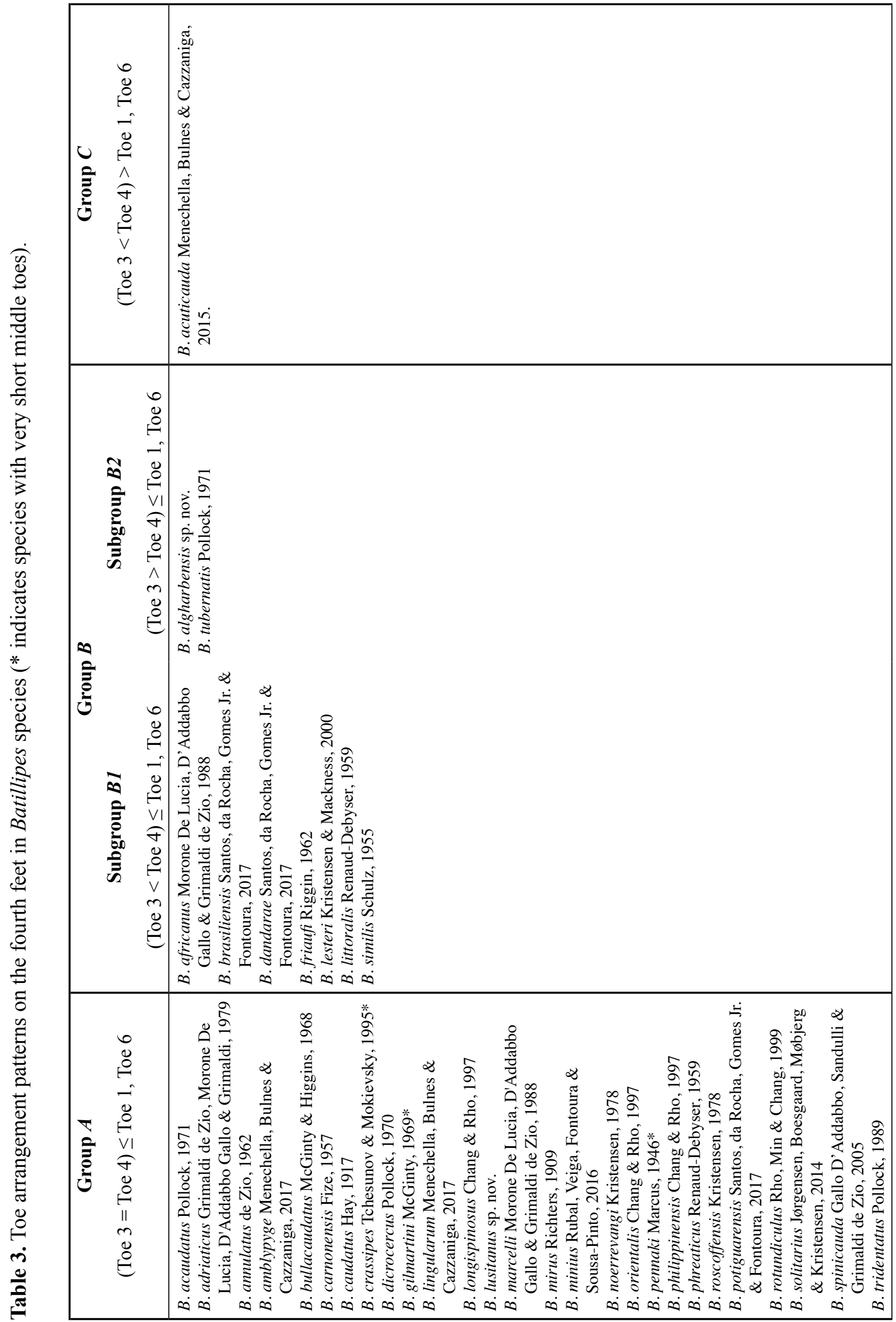


D’Addabbo Gallo, Morone De Lucia \& de Zio Grimaldi, 1989. Therefore, these results suggest that the Portuguese coast is the occidental boundary for some Mediterranean tardigrade species. Additionally, Rubal et al. (2016) also reported a new southern limit of B. tubernatis and S. haploceros Thulin, 1942 at the Portuguese coast. These boundary patterns suggested by the genera Batillipes and Styraconyx (i.e., southern limit for boreal and northern limit for warmer water species) is in agreement with observations on other marine groups such as macroalgae (Ardré 1971) or gastropods (Rubal et al.2013a). This study also supports the need for more extensive and deeper surveys. Despite the interesting biological information that they can provide (de Zio Grimaldi \& Gallo D'Addabbo 2001; Faurby et al. 2011, 2012), biogeographical studies on marine tardigrades, and especially on Batillipes, are scarce, often restricted to generalist lists (e.g., Kaczmarek et al. 2015; Miller \& Perry 2016) and sometimes leading to contradictory interpretations. Actually, results of recent studies suggested that geographic/ecological factors can act as barriers, promoting speciation (e.g., Faurby et al. 2011, 2012; Zawierucha et al. 2015; Faurby \& Barber 2015) contrary to hypotheses in favour

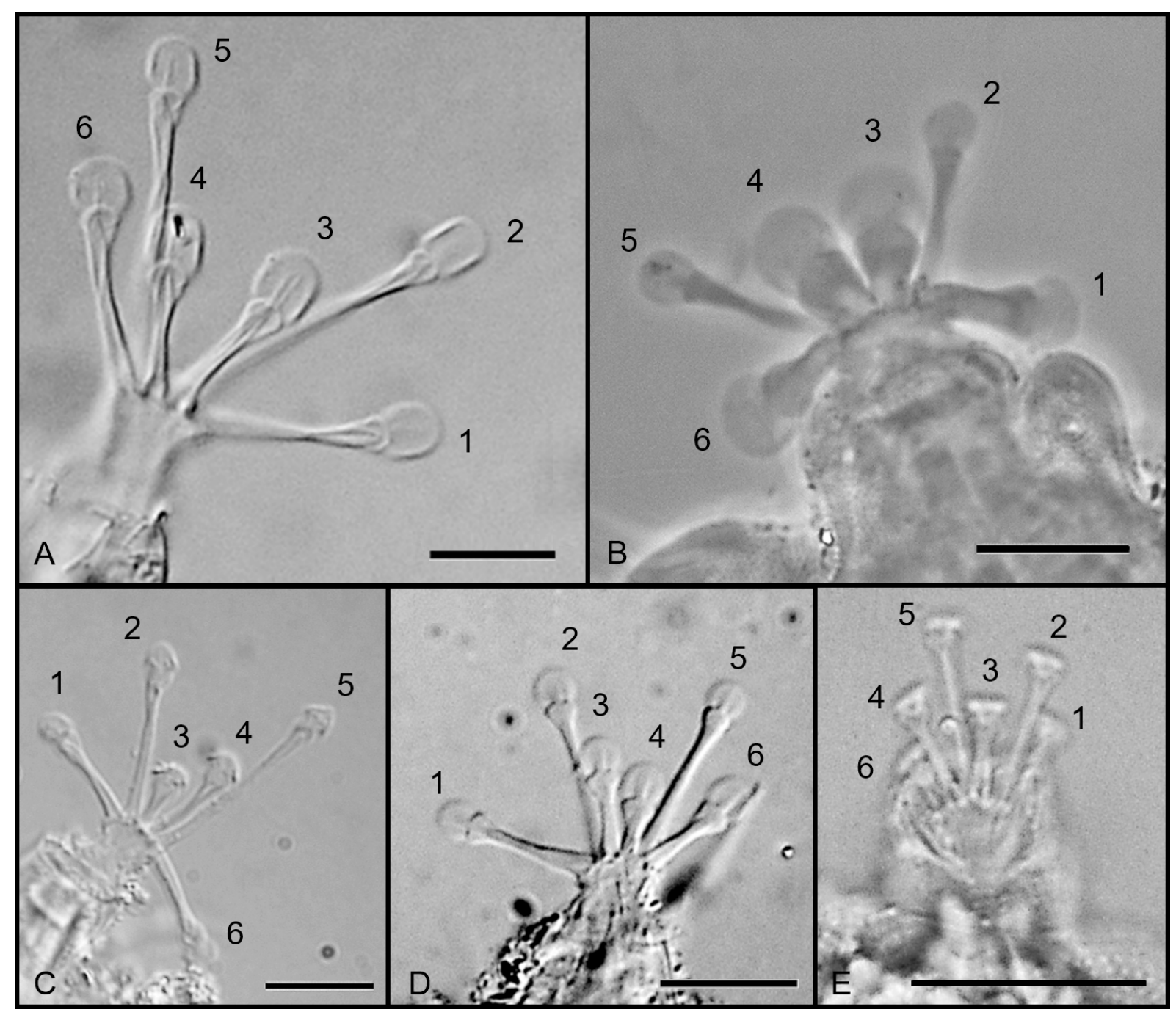

Fig. 9. Patterns of toe arrangement on the fourth feet of species of Batillipes Richters, 1909 (see text for details; toe 1 is the most cephalically). A. Group $A$ (B. lusitanus sp. nov.). B. Group $A$ with very short middle toes (B. pennaki Marcus, 1946). C. Group B, subgroup B1 (B. brasiliensis Santos, da Rocha, Gomes Jr. \& Fontoura, 2017). D. Group B, subgroup B2 (B. algharbensis sp. nov.). E. Group $C$ (B. acuticauda Menechella, Bulnes \& Cazzaniga, 2015). Scale bars $=10 \mu \mathrm{m}$. 
of wide-ranging species (e.g., Hummon 1994). Therefore, further studies in new habitats such as different depths (e.g., Hansen 2005), diverse environmental gradients (e.g., Pollock 1970b, 1989; Kristensen \& Mackness 2000; Faurby et al. 2012) or types of substrates (e.g., Rubal et al. 2016), would enhance our understanding of tardigrade distribution, and, particularly, could be pivotal to our understanding of the biogeography of the genus Batillipes.

\section{A dichotomous key to the identification of species of Batillipes}

Traditionally, keys to the identification of species of Batillipes used the caudal apparatus (e.g., Ramazzotti \& Maucci 1983) as the main distinguishing trait. However, after the discussion of the variability of taxonomic characters within the genus (McKirdy 1975; Gallo D'Addabbo et al. 2000), this trait, unless peculiar for some species or when combined with other characters, is no longer valid. Recently, a comprehensive key to all known species of Batillipes was published by Menechella et al. (2017). This key used the toe arrangement pattern, suggested by Kristensen \& Mackness (2000), as the first differentiating character. However, this key is no longer practical on account of the inaccuracies on the definition of toe patterns referred to in the present study. Therefore, a new key is provided, using a new proposal of toe arrangement patterns, shape of primary clava, ventral body projections between legs III-IV and details of cuticular sculpture as main taxonomic characters, allowing an easier identification based on observations under light microscopy (particularly PCM or DIC).

The shape and development of lateral body projections, as well as the relative size of leg sensory organs, also secondarily considered in the key, are ontogenetically variable characters (Villora-Moreno \& de Zio Grimaldi 1993; Gallo D'Addabbo et al. 2000), for this reason only adult specimens should be identified using the proposed key and more than one character should be used.

For a more accurate identification of some species, several characters are given in the last identification step. Unfortunately, for some old described species, some reliable attributes are unknown (e.g., details of punctation) and its presence/absence cannot be assumed, making the construction of identification keys for species of Batillipes an ongoing process.

Given that B. tubernatis Pollock, 1971 and B. crassipes Tchesunov \& Mokievsky, 1995 were the object of very different redescriptions, by McKirdy (1975) and Rho et al. (1999), respectively, different options of identification are provided in this key.

\section{Dichotomous key}

1. Middle toes ( 3 and 4$)$ on feet of legs IV equal in length (considering toe 1 the most cephalically) (species group $A$ )

- Middle toes ( 3 and 4 ) on feet of legs IV of different lengths (species groups $B$ and $C$ ) ................ 29

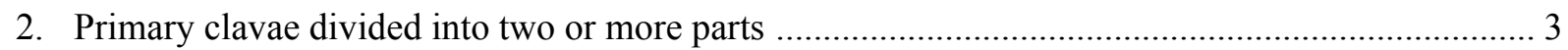

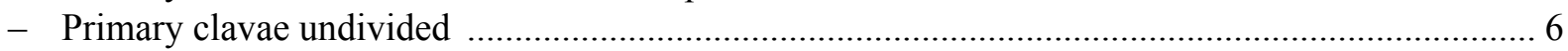

3. Primary clavae divided into two portions by a constriction ........................................................ 4

- Primary clavae divided into 6 portions by four constrictions .................. B. annulatus de Zio, 1962

4 Well developed lateral body projections between legs III and IV; caudal spine present and inserted on a basal support; folds on dorsal cuticle barely visible or indistinct .....

- Lateral body projections slight; caudal spine inserted directly on body cuticle; marked dorsal cuticular folds, appearing as segmental plates

B. gilmartini McGinty, 1969 
5 Body projections between legs III and IV lobate-shaped with rounded contour, primary clavae with two parts almost identical and markedly separated by a deep incision. Femur of legs IV very broad and short

B. pennaki Marcus, 1946

- Body projections between legs III and IV are large and conical with a terminal portion sometimes spike-shaped; primary clavae with two different parts, the first one stiff and the second slightly wrinkled. Femur on legs IV not particularly broad and short, appearing as typical of the majority of Batillipes species

B. spinicauda Gallo D'Addabbo, Sandulli \& de Zio Grimaldi, 2005

6. Dorsal cuticle, with or without scattered and randomly distributed larger dots, constituted of uniformly distributed large pillars (ca 5-7 pillars/ $10 \mu \mathrm{m}$, each $3 \mu \mathrm{m}$ high) that can appear as large tubercles (diameter ca $3 \mu \mathrm{m}$ )

- Dorsal cuticle with a different aspect, constituted of the typical Batillipes fine punctation (more than 8-10 pillars $/ 10 \mu \mathrm{m}$, each less than $1.5 \mu \mathrm{m}$ high). Dorsal punctation can be uniformly distributed, or it can have simultaneously apunctate areas, finely punctated areas and areas with more roughly punctuation

7. Dorsal cuticle roughly sculptured with scattered and randomly distributed larger dots (like "smallpox" in the terminology of Kristensen 1978). Caudal apparatus absent and replaced by a small groove; cephalic appendages very long (cirrus $A$ ca $100 \mu \mathrm{m}$ long, corresponding to $40 \%$ of body length); toes with elongated elliptical suction discs with a cut terminal edge

B. roscoffensis Kristensen, 1978

- Dorsal cuticle without scattered dots, sculptured by uniformly distributed dorsal pillars, appearing as large tubercles (diameter ca $3 \mu \mathrm{m}$ ). Caudal apparatus present; cephalic appendages not particularly long (cirrus $A$ less than $50 \mu \mathrm{m}$ long, corresponding to ca $20-28 \%$ of body length); toes with circular to ovoid suction discs

8. Lateral body projections between legs III and IV conical and sharply pointed; the caudal apparatus consists of a sharp and long spine inserted on cylindrical base (occasionally the caudal spine is bifid or could have accessory points at the base). Processes on the lateral surface of legs IV absent ......... B. adriaticus Grimaldi de Zio, Morone De Lucia, D'Addabbo Gallo \& Grimaldi, 1979

- Lateral body projections between legs III-IV blunt or slightly pointed; the caudal apparatus is a roundish cuticular expansion. A small rigid process is present on the lateral surface of legs IV

B. lusitanus sp. nov.

9. Well developed and conspicuous wing-shaped body projections between legs III and IV ............ 10

- Body projections between legs III and IV absent or reduced to short protuberances, papillae, spines or tooth-shaped

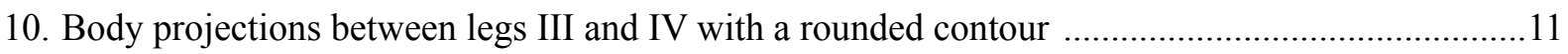

- Body projections between legs III and IV conical with one or two sharp points .......................... 23

11. Caudal apparatus consists of one or two spine-shaped appendages .............................................. 12

- Caudal apparatus indistinct or consisting of a more or less prominent blunt projection ................. 14

12. Femur of legs IV very broad and short. Body box-shaped; middle toes ( 3 and 4 ) on feet of legs IV very short (so short that suction discs resemble sessile); caudal apparatus consists of a spine barely protruding beyond edge of the body and inserted on a basal support; indistinct secondary clavae

B. crassipes (sensu Rho et al. 1999)

- Femur of legs IV not particularly broad and short as typical of the majority of species of Batillipes. Worm-like body with marked transversal cuticular folds; middle toes ( 3 and 4) on feet of legs IV, 
although shorter than the other digits, with well-developed stalks; caudal apparatus consists of one or two spines directly inserted on body cuticle; visible secondary clavae

13. Caudal apparatus consists of two spines (occasionally none); sensory organ on leg I turning frontwards, a pseudo-papilla is present in the transitional zone between the proximal and distal part of the legs

B. noerrevangi Kristensen, 1978

- Caudal apparatus consists of a single large spine; sensory organ on leg I turning backwards; pseudopapillae on legs absent

B. minius Rubal, Veiga, Fontoura \& Sousa-Pinto, 2017

14. Lateral cirri and internal cephalic cirri with terminal tufts; concave and elongated lens-shaped secondary clavae (13 $\mu \mathrm{m}$ wide); sharp pointed lateral processes between legs I-II, blunt between legs II-III; blunt and indistinct caudal apparatus; toes with ovoid suction discs; scapular region not protruding laterally at the level of the first pair of legs

B. solitarius Jørgensen, Boesgaard, Møbjerg \& Kristensen, 2014

- Plain tipped lateral and internal cephalic cirri; papillary (3-6 $\mu \mathrm{m}$ wide) or indistinct secondary clava; blunt lateral processes between all leg pairs; caudal apparatus consists of a prominent semicircular projection; toes with spatula-like suction discs; scapular region well developed, protruding laterally at the level of the first pair of legs

15. Sharply pointed cephalic cirri; secondary clavae indistinct; sensory organs on leg I shorter than sensory organs on leg IV that are spike-shaped; medial toes $(3,4)$ and external toes $(1,6)$ on feet of legs IV similar in length

B. rotundiculus Rho, Min \& Chang, 1999

- Cephalic cirri with swollen tips; papillary secondary clavae (3-6 $\mu \mathrm{m}$ wide); sensory organs on leg I longer than sensory organs on leg IV that are clearly divided into two portions, the distal portion with swollen tip; medial toes (3 and 4) on feet of legs IV much shorter than external toes (1, 6) B. potiguarensis Santos, da Rocha, Gomes Jr. \& Fontoura, 2017

16. Caudal apparatus consists of a spine inserted on a basal support

- Caudal apparatus absent or, if present, with a different constitution, consisting of a pointed triangular appendage or one or two caudal spines but, in this case, directly inserted on body cuticle and never inserted on a basal support

17. Femur of legs IV very broad and short. Middle toes (3 and 4) on feet of legs IV very short (so short that suction discs resemble sessile); projections between legs III and IV absent (very small projections can be present in females); caudal apparatus consists of a short spine barely protruding beyond the edge of the body; very short sensory organs on legs IV

B. crassipes Tchesunov \& Mokievsky, 1995 (s. str.)

- Femur of legs IV not particularly broad and short as typical of the majority of Batillipes species. Middle toes ( 3 and 4 ) on feet of legs IV although shorter than the other digits with well visible stalks; projections between legs III and IV in the shape of small tooth; caudal apparatus consists of a long spine reaching the level of toes of legs IV; very long sensory organs on legs IV also reaching the level of toes of legs IV

B. carnonensis Fize, 1957

18. Caudal apparatus absent

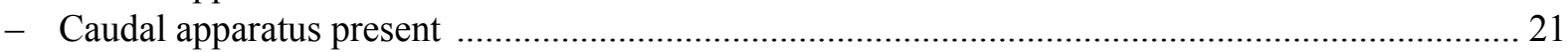

19. Primary clavae much shorter than lateral cirri $A$

- Primary clavae and lateral cirri $A$ similar in length

B. amblypyge Menechella, Bulnes \& Cazzaniga, 2017 
20. Cephalic appendages long (lateral cirri $A$ ca $14 \%$ of body length); sensory organ on leg IV very long (ca $14 \%$ of body length), reaching, at least, the level of middle toes

B. longispinosus Chang \& Rho, 1997

- Cephalic appendages short (lateral cirri $A$ ca $9 \%$ of body length); sensory organ on leg IV very short (ca $4 \%$ of body length)

B. acaudatus Pollock, 1971

21. Body with the ventro-lateral region between legs III and IV much swollen; caudal apparatus consists of a cuticular conical projection; prominent lateral body projections between the three first leg pairs are present

B. philippinensis Chang \& Rho, 1997

- Body box-shaped without the ventro-lateral region between legs III and IV particularly swollen; caudal appendage is a spine (occasionally absent) directly inserted on body cuticle; lateral body projections between legs reduced or absent

22. Large sized (the largest within the genus, $400-600 \mu \mathrm{m}$ in adult specimens); toes with large elliptical suction discs (ca $4 \mu \mathrm{m}$ wide and $6 \mu \mathrm{m}$ long); Projection between legs III-IV, if present, is a short spine

B. mirus Richters, 1909

- Small sized Batillipes (ca $160 \mu \mathrm{m}$ ); toes with small roundish suction discs. Projection between legs III-IV indistinct

B. caudatus Hay, 1917

23. Paired sharply-pointed body projections between legs III and IV; lateral surface of legs IV with a prominent rigid spike (in addition to the long sensory organ); caudal apparatus consists of a twopointed appendage

B. tridentatus Pollock, 1989

- Single conical body projections between legs III and IV; spike on legs IV absent (a small papilla can be present); caudal apparatus consists of one-, two- or multi-pointed appendage

24. Caudal apparatus absent (the terminal edge of the body is flattened)

B. orientalis Chang \& Rho, 1997

- Caudal apparatus present

25. Caudal apparatus consists of a single spine, terminating in a sharp point or in a swollen balloon-like structure

- Caudal apparatus consists of a two-pointed or multi-pointed appendage, in this case constituted by one major pointed spine surrounded, at its base, by a crown of small accessory spines

26. Caudal apparatus consists of a long vertical spine, terminating in a swollen balloon-like structure (this structure is occasionally absent); cephalic cirri (except external cirri) frayed (generally trifid) B. bullacaudatus McGinty \& Higgins, 1968

- Caudal apparatus consists of a sharp spine directed backwards; cephalic cirri with lance-like tips

27. Head with tongue-like projections behind the common pedestals bearing primary clavae and lateral cirri $A$; sensory organ on leg IV very long (ca $25 \%$ of body length), longer than legs IV; dorsal cuticle uniformly punctated ( $8-10$ pillars $/ 10 \mu \mathrm{m}$ ); papillae on legs absent; caudal spine inserted directly on body cuticle

B. lingularum Menechella, Bulnes \& Cazzaniga, 2017

- Head without tongue-like projections behind the common pedestals bearing primary clavae and lateral cirri $A$; sensory organ on leg IV short (ca 10\% of body length), shorter than legs $\mathrm{IV}$; dorsal cuticle not uniformly punctated, it is finely punctated in the dorsal medial region (about 14 pillars $/ 10 \mu \mathrm{m}$ ) and more roughly (ca 10 pillars $/ 10 \mu \mathrm{m}$ ) in dorsal margins of the body, head and caudal regions; papillae on legs present; caudal spine inserted on a basal support

B. marcelli Morone De Lucia, D’Addabbo Gallo \& Grimaldi de Zio, 1988 
28. Caudal apparatus constituted by a one major sharp spine surrounded, at its base, by a crown of small accessory spines; surface of primary clavae with black punctations

B. phreaticus Renaud-Debyser, 1959

- Caudal apparatus constituted by a two-pointed appendage without basal accessory spines; black punctations on primary clavae not observed

B. dicrocercus Pollock, 1970

29. On feet of legs IV, the middle toe 3 is shorter than the middle toe 4 (Group $C$ and $B$, subgroup B1)

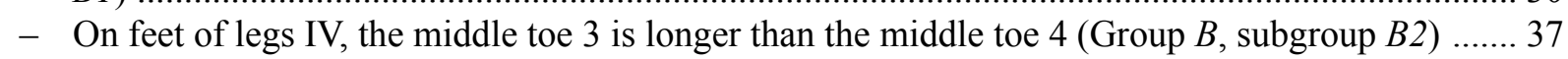

30. On feet of legs IV, toes 2 and 5 are the longest and middle toes 3 and 4 are shorter (or similar) than lateral toes 1 and 6, which are of intermediate length (subgroup B1). Primary clavae shorter than lateral cirri $A$

- On feet of legs IV, toes 2 and 5 are the longest and middle toes 3 and 4 are much longer than lateral toes 1 and 6 , which are the shortest (Group $C$ ). Primary clavae longer than lateral cirri $A$

B. acuticauda Menechella, Bulnes \& Cazzaniga, 2015

31. Lateral body projections between legs absent (in one species, B. friaufi, a very small papilla, less than $5.0 \mu \mathrm{m}$, is occasionally present between legs III and IV) 32

- Prominent lateral body projections, especially between legs III and IV (longer than $10.0 \mu \mathrm{m}$ ), present

32. Caudal apparatus consists of a pointed single triangular appendage more or less elongate (occasionally absent), exhibiting variability in shape and size among specimens; sensory organs II and III without annulated bases; dorsal cuticle uniformly punctated 33

- Caudal apparatus consists of a trifurcate caudal appendage with lateral spikes shorter than central spike; leg sensory organs II and III with annulated bases; dorsal cuticle with small apunctate areas B. friaufi Riggin, 1962

33. Scapular region with a conspicuous dorsal blunt enlargement; sensory organs on legs I spine-like, inserted in the posterior region of the legs and turned frontwards; sensory organs on legs III long (range 10.0-11.2 $\mu \mathrm{m}$ in adults 127-225 $\mu \mathrm{m}$ long); tibial papilla on legs absent

B. dandarae Santos, da Rocha, Gomes Jr. \& Fontoura, 2017

- Scapular region not enlarged; sensory organs on legs I articulated, straight and parallel to the toes; sensory organs on legs III short (range 5.0-7.0 $\mu \mathrm{m}$ in adults $122-212 \mu \mathrm{m}$ long); tibial papilla on legs present

B. africanus Morone De Lucia, D’Addabbo Gallo \& Grimaldi de Zio, 1988

34. Caudal apparatus consisting of an ala-like structure often covered with detritus, exhibiting great variability (simple, bilobed, highly furcate); lateral body projections between legs III and IV with more than one point

- Caudal apparatus consisting of a broad-based spiky process, sharpening distally or of a single conical/triangular-shaped process; lateral body projections between legs III and IV with single point

35. Lateral body projections between legs III and IV two-pointed (in adults); external cephalic cirri horn-shaped; sensory organ on legs IV long (ca $20 \%$ of body length); cuticular projections on legs absent B. lesteri Kristensen \& Mackness, 2000

- Lateral body projections between legs III and IV with fringed distal edge (usually more than two blunt fringes); external cephalic cirri terminated by a swollen tip; sensory organ on legs IV much short (ca $10 \%$ of body length); small semicircular cuticular projections present on the coxal region of legs I-III B. brasiliensis Santos, da Rocha, Gomes Jr. \& Fontoura, 2017 
36. Caudal apparatus consists of a three pointed spiky process. Primary clavae uniformly tubular; legs IV with a lateral sharp tooth B. littoralis Renaud-Debyser, 1959

- Caudal apparatus consists of a single conical projection. Primary clavae drumstick-like; lateral tooth on legs IV absent B. similis Schulz, 1955

37. Lateral body projections between all pairs of legs absent. Tube-shaped primary clavae and indistinct secondary clavae; dorsal cuticle uniformly finely punctated (ca 15 pillars $/ 10 \mu \mathrm{m}$ ) or exhibiting simultaneously apunctate areas, finely punctated areas and areas with more roughly punctuation ...

- Blunt lateral body projections between all leg pairs (small between legs I-III, very well-developed between legs III-IV). Very thin sharp-pointed primary clavae and strongly developed secondary clavae; dorsal cuticle uniformly coarsely punctated (ca 9-10 pillars/ $10 \mu \mathrm{m}$ )

B. algharbensis sp. nov.

38. Caudal region is always swollen and rounded; dorsal cuticle uniformly finely punctuated (ca 14-15 pillars $/ 10 \mu \mathrm{m}$ ); toe discs ovoid and not indented on the distal edge; dorsal leg papillae absent

B. tubernatis Pollock, 1971 (s. str.)

- Caudal region usually (ca $80 \%$ of the specimens) with a strong swollen-based caudal spike (ca $20 \%$ of the specimens without caudal appendage and a few with a small off-center caudal spur); dorsal cuticle not uniformly punctated (dorsolateral and cephalic punctations larger, ca 9 pillars $/ 10 \mu \mathrm{m}$, than in the other dorsal zones, ca 15 pillars / $10 \mu \mathrm{m}$ that also have 7 transversal apunctate areas); toe discs quadrate with a slightly indented distal edge; dorsal leg papilla present

B. tubernatis (sensu McKirdy 1975)

\section{Acknowledgements}

The authors are grateful to the colleagues of MARE (Marine and Environmental Sciences Centre) Sílvia Tavares, Emanuel Gonçalves, João Cabral and Pedro Duarte Coelho, for invaluable support during field expeditions for sampling at Portinho da Arrábida Beach and Vasco da Gama Beach. A very special acknowledgement is also due to the staff members of "Muséum national d'Histoire naturelle de Paris" (MNHN), notably to Cédric Hubas, the curator of the Collection of Meiofauna, and also to Dominique Lamy, Coralie Martin and Fréderic Fercoq for friendship, support and facilities provided during our visit in Paris to examine type material of species of Batillipes. We also thank Paul J. Bartels (Warren Wilson College, USA) who kindly provided important information about specimens from the collection of L. Pollock, including photo 8D, Agustín G. Menechella (Universidad Nacional del Sur, Argentina) who provided photo 9E of B. acuticauda, and Carlos Sá, the Director of CEMUP (Materials Centre of the University of Porto) for facilities provided for SEM microscopy. This research was partially funded by the Fundação para a Ciência e a Tecnologia - FCT (partially FEDER funded) through the projects: UID/Multi/04423/2013 and through MARE (UID/MAR/04292/2013), and by the European Regional Development Fund (ERDF) through the programme POFCCOMPETE, 'Quadro de Referência Estratégico Nacional (QREN). During this study, Erika Santos was supported by a doctoral grant (BEX 13580/13-2) awarded by CAPES (Coordination of Improvement of Higher Level Personnel), Brazil; Marcos Rubal (SFRH/BDP/104225/2014) and Puri Veiga (SFRH/ BPD/81582/2011) were supported by postdoctoral grants awarded by Fundacão para a Ciência e Tecnologia, Portugal. Finally, we acknowledge the anonymous referees for their valuable critical remarks and comments.

\section{References}

Ardré F. 1971. Contribution à l'étude des algues marines du Portugal II. Écologie et chorologie. Bulletin du Centre d'Études et de Recherches Scientifiques, Biarritz 8: 359-574. 
Bartels P.J., Apodaca J.J., Mora C. \& Nelson D. 2016. A global biodiversity estimate of a poorly known taxon: phylum Tardigrada. Zoological Journal of the Linnean Society 178 (4): 730-736.

https://doi.org/10.1111/zoj.12441

Degma P. \& Guidetti R. 2007. Notes to the current checklist of Tardigrada. Zootaxa 1579: 41-53.

Degma P., Bertolani R. \& Guidetti R. 2009-2017. Actual checklist of Tardigrada species. Available from: http://www.tardigrada.modena.unimo.it/miscellanea/Actual\%20checklist $\% 20$ of $\% 20$ Tardigrada.pdf [accessed on 19 Jun. 2017].

de Zio S. 1962. Descrizione di Batillipes annulatus n. sp. e note su Batillipes pennaki Marcus, nuovo rinvenimento nel Mediterraneo (Hetrotardigrada). Annuario dell Istituto e Museo di Zoologia della Universita di Napoli 14 (6): 1-7.

de Zio Grimaldi S. \& Gallo D'Addabbo M. 2001. Further data on the Mediterranean Sea tardigrade fauna. Zoologischer Anzeiger 240 (3): 345-360.

Faurby S. \& Barber P. H. 2015. Extreme population subdivision despite high colonization ability: contrasting regional patterns in intertidal tardigrades from the west coast of North America. Journal of Biogeography 42 (6): 1006-1017. https://doi.org/10.1111/jbi.12500

Faurby S., Jørgensen A., Kristensen R.M. \& Funch P. 2011. Phylogeography of North Atlantic intertidal tardigrades: refugia, cryptic speciation and the history of the Mid-Atlantic Islands. Journal of Biogeography 38 (8): 1613-1624. https://doi.org/10.1111/j.1365-2699.2011.02533.x

Faurby S., Jørgensen A., Kristensen R.M. \& Funch P. 2012. Distribution and speciation in marine intertidal tardigrades: testing the roles of climatic and geographical isolation. Journal of Biogeography 39: 1596-1607. https://doi.org/10.1111/j.1365-2699.2012.02720.x

Fontoura P., Bartels P. J., Jørgensen A., Kristensen R.M. \& Hansen J.G. 2017. A dichotomous key to the genera of the Marine Heterotardigrades (Tardigrada). Zootaxa 4294 (1): 1-45.

https://doi.org/10.11646/zootaxa.4294.1.1

Gallo D'Addabbo M., D'Addabbo R. \& de Zio Grimaldi S. 2000. Redescription of Batillipes dicrocercus Pollock, 1970 and revision of the genus Batillipes (Tardigrada, Heterotardigrada). Zoologischer Anzeiger 239: 329-330.

Gallo D'Addabbo M., Sandulli R. \& de Zio Grimaldi S. 2005. A new Batillipedidae (Tardigrada, Heterotardigrada) from the Orosei Gulf, Sardinia, Tyrrhenian Sea. Zoologischer Anzeiger 243: 219-225. https://doi.org/10.1016/j.jcz.2004.07.004

Grimaldi de Zio S., Morone De Lucia M.R., D’Addabbo Gallo M. \& Grimaldi P. 1979. Osservazioni su alcuni tardigradi di una spiaggia pugliese e descrizione di Batillipes adriaticus sp. nov. (Heterotardigrada). Thalassia Salentina 9: 39-50.

Guidetti R. \& Bertolani R. 2005. Tardigrade taxonomy: an updated checklist of the taxa and a list of characters for their identification. Zootaxa 845: 1-46. https://doi.org/10.11646/zootaxa.845.1.1

Hansen J.G. 2005. The ongoing investigation of the Faroe Bank tardigrade fauna. Frodskaparrit supplementum: Proceedings from the BIOFAR Symposium, Tórshavn, Faroe Islands, 24-26, April 2003, North-East Atlantic marine benthic organisms in the Faroes - taxonomy, distribution and ecology: 220-223.

Hummon W.D. 1994. Trans- and cis-Atlantic distributions of three marine heterotardigrades. Transactions of the American Microscopical Society 113 (3): 333-342. https://doi.org/10.2307/3226627 
Jørgensen A., Boesgaard T.M., Møbjerg N. \& Kristensen R.M. 2014. The tardigrade fauna of Australian marine caves: with descriptions of nine new species of Arthrotardigrada. Zootaxa 3802 (4): 401-443. https://doi.org/10.11646/zootaxa.3802.4.1

Kaczmarek Ł., Bartels P.J., Roszkowska M. \& Nelson D.R. 2015. The zoogeography of marine Tardigrada. Zootaxa 4037 (1): 1-189. https://doi.org/10.11646/zootaxa.4037.1.1

Kristensen R.M. 1978. Notes on marine heterotardigrades. 1. Description of two Batillipes species, using the electron microscope. Zoologischer Anzeiger 200: 1-17.

Kristensen R.M. \& Mackness B.S. 2000. First record of the marine Tardigrade genus Batillipes (Arthrotardigrada: Batillipedidae) from South Australia with a description of a new species. Records of the South Australian Museum 33 (2): 73-87.

Marcus E. 1946. Batillipes pennaki, a new marine tardigrade from the North and South American Atlantic coast. Comunicaciones Zoológicas del Museo de Historia Natural de Montevideo 2: 1-3.

McGinty M.M. \& Higgins R.P. 1968. Ontogenetic variation of taxonomic characters of two marine tardigrades with the description of Batillipes bullacaudatus n. sp. Transactions of the American Microscopical Society 87 (2): 252-262.

McKirdy D.J. 1975. Batillipes (Heterotardigrada): Comparison of six species from Florida (USA) and a discussion of taxonomic characters within the genus. Memorie dell'Istituto Italiano di Idrobiologia 32 (Supplement): 177-223.

Menechella A.G., Bulnes V.N. \& Cazzaniga N.J. 2017. Two new species of Batillipes (Tardigrada, Arthrotardigrada, Batillipedidae) from the Argentinean Atlantic coast, and key to all known species. Marine Biodiversity: 1-9. https://doi.org/10.1007/s12526-017-0640-4

Miller W.R. \& Perry E.S. 2016. The coastal marine Tardigrada of the Americas. Zootaxa 4126 (3): 375-396. https://doi.org/10.11646/zootaxa.4126.3.4

Morone De Lucia R.M., D’Addabo Gallo M. \& Grimaldi de Zio S. 1988. Descrizione di due nuove specie di Batillipedidae (Tardigrada: Heterotardigrada). Cahiers de Biologie Marine 29: 361-373.

Pollock L.W. 1970a. Batillipes dicrocercus n. sp., Stygarctus granulatus n. sp. and other Tardigrada from Woods Hole, Massachusetts, U.S.A. Transactions of the American Microscopical Society 89 (1): 38-52. https://doi.org/10.2307/3224613

Pollock LW. 1970b. Distribution and dynamics of interstitial Tardigrada at Woods Hole, Massachusetts, U.S.A. Ophelia 7: 145-166.

Pollock L.W. 1971. On some British marine Tardigrada, including two new species of Batillipes. Journal of the Marine Biological Association of the United Kingdom 51: 93-103.

https://doi.org/10.1017/S0025315400006482

Pollock LW. 1989. Marine interstitial Heterotardigrada from the Pacific Coast of the United States, including a description of Batillipes tridentatus n. sp. Transactions of the American Microscopical Society 108: 169-189. https://doi.org/10.2307/3226373

Ramazzotti G. \& Maucci W. 1983. Il phylum Tardigrada - III Edizione. Memorie dell'Istituto Italiano di Idrobiologia 41: 1-1012.

Renaud-Debyser J. 1959. Sur quelques tardigrades du bassin d'Arcachon. Vie et Milieu 10: 135-146.

Rho H.S., Min B.H. \& Chang C.Y. 1999. Taxonomic study of marine Tardigrades from Korea I. Genus Batillipes (Heterotardigrada: Batillipedidae). The Korean Journal of Systematic Zoology 15: 107-118. 
Richters F. 1909. Marine Tardigraden. Verhandlungen der deutschen Zoologischen Gesellschaft 19: 84-95.

Riemann F. 1966. Die interstitielle Faune in Elbe-Aestuar. Verbreitung und Systematik. Archiv für Hydrobiologie Supplementband 31: 1-279.

Rubal M., Veiga P., Cacabelos E., Moreira J. \& Sousa-Pinto I. 2013a. Increasing sea surface temperature and range shifts of intertidal gastropods along the Iberian Peninsula. Journal of Sea Research 77: 1-10. https://doi.org/10.1016/j.seares.2012.12.003

Rubal M., Veiga P., Fontoura P. \& Sousa-Pinto I. 2013b. A new intertidal arthrotardigrade, Prostygarctus aculeatus gen. nov., sp. nov. (Tardigrada: Heterotardigrada) from the North of Portugal (Atlantic Ocean). Journal of Limnology 72: 8-14. https://doi.org/10.4081/jlimnol.2013.s1.e2

Rubal M., Veiga P., Fontoura P., Santos E. \& Sousa-Pinto I. 2016. Biodiversity of marine tardigrades from the northern coast of Portugal (Iberian Peninsula). Zoological Journal of the Linnean Society 178: 747-754. https://doi.org/10.1111/zoj.12462

Rubal M., Veiga P., Fontoura P. \& Sousa-Pinto I. 2017. A new Batillipes (Tardigrada, Heterotardigrada, Batillipedidae) from North Portugal (Atlantic Ocean). Marine Biodiversity 47 (3): 921-928.

https://doi.org/10.1007/s12526-016-0526-X

Santos E., da Rocha C.M.C., Gomes Jr. E. \& Fontoura P. 2017. Three new Batillipes species (Arthrotardigrada: Batillipedidae) from the Brazilian coast. Zootaxa 4243 (3): 483-502.

https://doi.org/10.11646/zootaxa.4243.3.4

Schulz E. 1955. Studien an marinen tardigraden. Kieler Meeresforschungen 11: 74-79.

Veiga P., Rubal M. \& Besteiro C. 2009. Primera cita de Orzeliscus belopus Du Bois-Reymond Marcus, 1952 (Tardigrada, Arthrotardigrada) para la Península Ibérica, con notas sobre otros tardígrados encontrados en las rías de O Barqueiro y Foz (Galicia, NO Península Ibérica). Boletín de la Real Sociedad Española de Historia Natural Sección Biológica 103 (1-4): 57-63.

Villora-Moreno S. \& de Zio Grimaldi S. 1993. Redescription and ecology of Batillipes phreaticus Renaud-Debyser, 1959 (Arthrotardigrada, Batillipedidae) in the Gulf of Valencia (western Mediterranean). Cahiers de Biologie Marine 34: 387-399.

Zawierucha K., Grzelak K., Kotwicki L., Michalczyk Ł. \& Kaczmarek Ł. 2013. Batillipes pennaki Marcus, 1946, a new addition to the Thai tardigrade fauna, with an overview of literature on the species. Pakistan Journal of Zoology 45 (3): 801-808.

Zawierucha K., Grzelak K., Kotwicki L., Michalczyk Ł. \& Kaczmarek Ł. \& Kristensen R.M. 2015. First observation of the marine tardigrades Batillipes mirus and Batillipes noerrevangi (Arthrotardigrada, Batillipedidae) from a strongly brackish part of the Polish Baltic Sea coast. Marine Biology Research 11 (8): 859-868. https://doi.org/10.1080/17451000.2015.1024133

Manuscript received: 28 July 2017

Manuscript accepted: 5 December 2017

Published on: 12 April 2018

Topic editor: Rudy Jocqué

Desk editor: Pepe Fernández 
Printed versions of all papers are also deposited in the libraries of the institutes that are members of the EJT consortium: Muséum national d'Histoire naturelle, Paris, France; Botanic Garden Meise, Belgium; Royal Museum for Central Africa, Tervuren, Belgium; Natural History Museum, London, United Kingdom; Royal Belgian Institute of Natural Sciences, Brussels, Belgium; Natural History Museum of Denmark, Copenhagen, Denmark; Naturalis Biodiversity Center, Leiden, the Netherlands; Museo Nacional de Ciencias Naturales-CSIC, Madrid, Spain; Real Jardín Botánico de Madrid CSIC, Spain. 